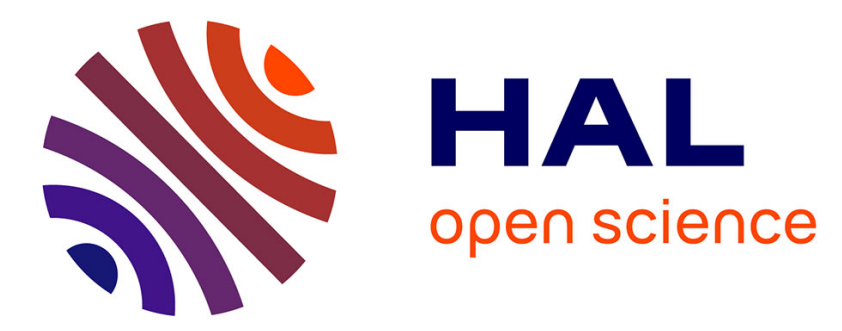

\title{
The Nazca Drift System - palaeoceanographic significance of a giant sleeping on the SE Pacific Ocean floor
}

Gérôme Calvès, Alan Mix, Liviu Giosan, Peter Clift, Stéphane Brusset, Patrice Baby, Mayssa Vega

\section{To cite this version:}

Gérôme Calvès, Alan Mix, Liviu Giosan, Peter Clift, Stéphane Brusset, et al.. The Nazca Drift System - palaeoceanographic significance of a giant sleeping on the SE Pacific Ocean floor. Geological Magazine, 2021, pp.1-15. 10.1017/S0016756821000960 . hal-03418522

\author{
HAL Id: hal-03418522 \\ https://hal.science/hal-03418522
}

Submitted on 12 Nov 2021

HAL is a multi-disciplinary open access archive for the deposit and dissemination of scientific research documents, whether they are published or not. The documents may come from teaching and research institutions in France or abroad, or from public or private research centers.
L'archive ouverte pluridisciplinaire HAL, est destinée au dépôt et à la diffusion de documents scientifiques de niveau recherche, publiés ou non, émanant des établissements d'enseignement et de recherche français ou étrangers, des laboratoires publics ou privés. 
1 The Nazca Drift System - paleoceanographic significance of a giant sleeping 2 on the SE Pacific Ocean floor.

3 Original Article

4 Author list: Gérôme Calvès ${ }^{1, *}$, Alan Mix ${ }^{2}$, Liviu Giosan ${ }^{3}$, Peter D. Clift ${ }^{4}$, Stéphane Brusset ${ }^{1}$, 5 Patrice Baby ${ }^{5}$ and Mayssa Vega ${ }^{6}$.

6 1. Université Toulouse III, GET-OMP, 14 avenue Edouard Belin, 31400, Toulouse, France. (orcid.org/0000-

7 0003-3829-131X)(*Corresponding author: gerome.calves@univ-tlse3.fr), stephane.brusset@univ-

8 tlse3.fr (orcid.org/0000-0002-7880-4514)

9 2. College of Earth, Ocean, and Atmospheric Sciences, Oregon State University, Corvallis, OR 97331, USA,

10 mix@coas.oregonstate.edu (orcid.org/0000-0001-7108-3534)

11 3. Geology \& Geophysics, Woods Hole Oceanographic Institution, Woods Hole, MA 02543, USA,

12 lgiosan@whoi.edu (orcid.org/0000-0001-6769-5204)

4. Department of Geology and Geophysics, E235 Howe-Russell, Louisiana State University, Baton Rouge, Louisiana 70803, USA, +1 225-578-2153, pclift@lsu.edu (orcid.org/0000-0001-6660-6388)

5. IRD, GET-OMP, 14 avenue Edouard Belin, 31400, Toulouse, France, patrice.baby@ird.fr (0000-00016142-5174)

6. Universidad San Antonio Abad del Cusco, Av. De la Cultura 773, 08000 Cusco. Peru, maria.vega@unsaac.edu.pe (orcid.org/0000-0003-2907-1171).

Short Title: Nazca Drift System - SE Pacific Ocean paleoceanography

\section{Abstract}

The evolution and resulting morphology of a contourite drift system in the SE Pacific oceanic basin is investigated in detail using seismic imaging and an age-calibrated borehole section.

The Nazca Drift System covers an area of $204,500 \mathrm{~km}^{2}$ and stands above the abyssal basins of Peru and Chile. The drift is spread along the Nazca ridge in water depths between 2,090 5,330 m. The Nazca Drift System was drilled at ODP Site 1237. This deep-water drift overlies faulted oceanic crust and onlaps associated volcanic highs. Its thickness ranges from 104 to $375 \mathrm{~m}$. The seismic sheet facies observed are associated with bottom currents processes. The main lithologies are pelagic carbonates reflecting the distal position relative to South America and water depth above the carbonate compensation depth during the Oligocene. The Nazca Drift System developed under the influence of bottom currents sourced from the Circumpolar Deepwater and Pacific Central Water, and is the largest yet identified abyssal drift system of the Pacific Ocean, ranking third in all abyssal contourite drift systems globally. The plate has subducted since the late Miocene and the excess of sediments and water associated with the Nazca Drift System may have contributed to the Andean orogeny and associated metallogenesis. The Nazca Drift System records the evolution in interactions between deep sea currents and eastward motion of the Nazca Plate through erosive surfaces and sediment remobilization.

Keywords: Nazca Ridge, Nazca Drift System, Contourite drift, Oligocene, SE Pacific Ocean, paleoceanography 
Nazca Drift System - SE Pacific Ocean paleoceanography /doi:10.1017/S0016756821000960

\section{Introduction}

The Nazca Ridge separates the Chile and Peru oceanic basins (Fig. 1a) (e.g. Kukowski et al., 2008). These two adjacent basins have their shallowest closed bathymetric contour at 3,600 m

water depth and are separated by the Nazca Ridge (Fig. 1a). These basins are open at sills and trenches where bottom water flow connects to the surrounding basins (Lonsdale, 1976; Harris et al. 2014; Harris and Macmillan-Lawler, 2018). The Nazca Ridge is a bathymetric high marked by numerous seamounts with elongated and rough morphology (Casalbore, 2018;

Harris et al., 2014). This aseismic ridge is being subducting under South American Plate (Pilger, 1981) interacting with the active margin by increasing tectonic erosion (von Huene, et al., 1996; Clift et al., 2003; Hampel, 2002; Hampel et al., 2004). Its influence is felt as far inboard as the Andes (e.g. Gutcher et al., 1999; Rousse et al., 2003) and possibly the Amazon foreland basin (Espurt et al., 2007). Two Ocean Drilling Program (ODP) sites, 1236 and 1237, have drilled this ridge, coring Oligocene to recent sediments with pelagic to hemipelagic facies (Tiedemann and Mix, 2007; Fig. 1a).

This region of the SE Pacific Ocean is a key location for understanding the interplay between plate tectonics and climate change because the oceanic domain is under the influence of southern and equatorial atmospheric cells and is famous for the Humboldt Current that flows along the coast of South America (von Humboldt, 1816; Shaffer et al., 2004; Chaigneau et al., 2013). The moving water masses here are the intermediate water of the Pacific Central Water (PCW; 1,500-3,000 m) which has a southward movement and the deep waters of the Circumpolar Deep Water (CDW, also known as CPDW; >3,000 m) that flows northward (Figs. 1b and 1c; Emery and Meincke, 1986; Tsuchiya and Talley, 1998; Talley, 2013). The 
Nazca Drift System - SE Pacific Ocean paleoceanography /doi:10.1017/S0016756821000960

66

67

68

69

70

71

72

73

74

75

76

77

78

79

80

81

82

83

84

85

86

shallow water currents are the Peru Coastal Current (PCC) and the Peru Oceanic Current

(POC) (Fig. 1a). The deep-water currents are: the poleward Peru-Chile Undercurrent (PCUC),

and Peru-Chile Counter Current (PCCC), and the northward flowing Chile-Peru Deep Coastal

Current (CPDCC; Chaigneau et al., 2013). The flow of water from the Sub-Antarctic Mode

Water/Antarctic Intermediate Water (SAMW/AAIW) into the Chile Basin is characterized by

a total equatorward transport of about 7 Sv (Shaffer et al., 2004). The bottom waters within

the study area are dominated by the AAIW and the CDW (Fig. 1b). Oxygen concentration

along a hydrographic section from the southern ocean to the equator $\left(\mathrm{ca} .85^{\circ} \mathrm{W}\right)$ illustrates the

vertical and spatial organization of the water masses and the direction of the current flow (Fig.

1c). In the SE Pacific Ocean, the deeper water masses consist of 40 to $60 \%$ AABW and 20 to

$30 \%$ NADW but it is important to note that the CDW has not been included in this analysis

(Johnson, 2008). The CDW is the bottom water in the SE Pacific north of the Chile Rise and

it is not affected by the AABW (Tsuchiya and Talley, 1998; Talley, 2013). The Peruvian

margin is strongly eroded by the bottom currents from the shelf to the base of slope (Calvès et al., 2017). The influence of the Andes and its uplift on oceanic currents has been modeled

(Sepulchre et al., 2009) despite limited documentation of geological features (Lonsdale \&

Malfait, 1974; Lonsdale, 1976) related to oceanic currents, such as the Humboldt Current.

The SE Pacific is under the influence of the Antarctic Circumpolar Current (ACC), with a

dated onset of Oligocene age (e.g. Barker et al., 2007; Lyle et al., 2007; Scher et al., 2015).

This setting of oceanic basins and bathymetric highs bathed by moving water masses is prone

to mobilization of sediments by bottom water currents and the emplacement of contourite 
Nazca Drift System - SE Pacific Ocean paleoceanography /doi:10.1017/S0016756821000960

drifts (Lonsdale \& Malfait, 1974; Lonsdale, 1976; Esentia et al., 2018; Juan et al., 2018), despite low predicted velocities at the seafloor (Thran et al., 2018). We document the first regional compilation of surface and subsurface data to describe the Nazca Drift System in the evolution of the southern hemisphere oceanic cell. More generally we seek to understand the role that vertical motion of water masses and seafloor bathymetry has in shaping open ocean contourite drift in the SE Pacific Ocean, since the Oligocene.

\section{Methods}

Data are sourced from various vintage seafloor bathymetric surveys and seismic reflection acquisitions acquired since the 1960's (NOAA-NCEI;

https://www.ngdc.noaa.gov/mgg/mggd.html). The main source of regional seismic profiles is the analog seismic reflection profile databank at the Lamont-Doherty Earth Observatory (LDEO) and single channel seismic (SCS) profiles: RC0904, RC0905, RC1306, RC1307, RC1804 and RC2108 (https://www.ngdc.noaa.gov/mgg/seismicreflection/index.html). A more recent seismic reflection site survey (GENEO3RR, 1997) was acquired to plan drilling sites for ODP Leg 202 (Fig. 1a; Tiedemann and Mix, 2007). The vintage SCS have a lower vertical resolution compared to the modern SCS that have a peak frequency of 55-60 Hz. ODP Site 1237 provides ages for calibrating the seven interpreted seismic reflections from the acoustic basement to the seafloor (Tiedemann and Mix, 2007).

The seafloor has been mapped using multibeam bathymetric data (NOAA-NCEI multibeam bathymetry; https://www.ngdc.noaa.gov/maps/autogrid/) across the Nazca Ridge and surrounding Peru and Chile basins (Fig. 2a). The regional bathymetry is sourced from the General Bathymetric Chart of the Oceans (GEBCO) compilation group (2019; https://www.gebco.net/data_and_products/gridded_bathymetry_data/). The main lithologies outcropping at the seafloor are calcareous oozes and other fine-grained calcareous sediments overlying the Nazca Ridge igneous basement, and siliciclastic clay and diatom oozes in the 
Nazca Drift System - SE Pacific Ocean paleoceanography /doi:10.1017/S0016756821000960

112

113

114

115

116

117

118

119

120

121

122

123

124

125

126

127

128

129

130

131

132

133

134

135

136

137

surrounding basins (Dutkiewicz et al., 2015;

ftp://ftp.earthbyte.org/papers/Dutkiewicz_etal_seafloor_lithology/). The seafloor geomorphology (Fig. 2b) follows the previous interpretation of Harris et al. (2014). The seismic dataset over the Nazca Ridge and surrounding area covers most of the different abyssal to trench settings (or features) identified by Harris et al. (2014). Seafloor depths range from 1,550- 5,270 $\mathrm{m}$ in the SE Pacific Ocean, offshore Peru (Fig. 1a). The uninterpreted seismic data are in the supplementary Figure S1 and S2. The seismic data displayed in this study are zero phase and have the Society of Exploration Geophysicists (SEG) normal polarity, i.e., black peak indicating an increase in acoustic impedance. With a dominant frequency of $55-60 \mathrm{~Hz}$ and a velocity of $1,800 \mathrm{~m} / \mathrm{s}$, the seismic resolution, defined as a quarter of the dominant wavelength, would be $7-9 \mathrm{~m}$. We use a constant velocity $(1,500 \mathrm{~m} / \mathrm{s})$ for depth conversion of the seafloor from time to depth domain. Depth conversions of the sediments are based on a velocity of 1,800 $\pm 200 \mathrm{~m} / \mathrm{s}$ derived from the refraction profiles in the eastern part of the study area (Hampel et al., 2004) and two sonobuoy solutions (C13-30 and C13-32; Fig. 1; Diebold, 1996). No velocity measurements on sediments or wireline logs has been acquired within the study area.

The 2-D seismic data in this study have been interpreted using standard seismic stratigraphic techniques (Mitchum et al., 1977; Vail et al., 1977) based on reflection terminations and seismic facies reflection characteristics (amplitude, frequency). The seafloor reflection shows concordance (no termination) or truncation (erosional or structural) and together with the surrounding reflections is interpreted as a sequence boundary (Mitchum et al., 1977). A megasequence is defined between the acoustic basement and the seafloor reflection. In the focus study site near ODP Site 1237 a detailed analysis of the seismic units with age calibration is possible (Fig. 1). The seismic facies are summarized in Figure 3. Two class of seismic facies are observed, the first is associated with volcanic/oceanic crust features (e.g. Calvès et al., 2011) and the second to bottom current-induced sedimentary features (e.g. 
Nazca Drift System - SE Pacific Ocean paleoceanography /doi:10.1017/S0016756821000960

138 Faugères et al., 1999; Dubois and Mitchell, 2012; Rebesco and Stow; 2001; Rebesco et al.,

1392014 and references within; Bailey et al., 2021). A regional cross section and isopach map of

140 the megasequence allows identification of the main depocenters (Fig. 4). Oceanographic data

141 (temperature, salinity, oxygen) are sourced from the National Oceanic and Atmospheric

142 Administration (NOAA) World Ocean Database (WOD13) (Boyer et al., 2013).

\section{3. $\quad$ Results}

145 3.a Seafloor morphology

146 The Nazca Ridge divides the study area along a SW-NE axis and separates the Chile and Peru

147 Basins (Fig. 2a). Within the study area we have identified, seaward of the Peru-Chile Trench,

148 the transition of seafloor types/morphologies from faulted oceanic crust type morphology ( $\alpha$,

149 Fig. 2a), volcanic mound/seamount ( $\beta$, Fig. 2a), to smooth seafloor associated to hemipelagic

150 sedimentation and contourite drifts ( $\gamma$, Fig. 2a). The faulted oceanic crust seafloor type shows various sedimentary cover, with very thin drape toward the spreading centre of the East Pacific Rise to thicker sedimentary cover and smoother seafloor toward the trench. The oceanic crust around the Nazca Ridge is linked to fast accretion at ca.100 mm/yr (Wright et al., 2016), as expressed by the numerous faults observed at the seafloor (Fig. 2a - inset $\alpha$ ) that mark the abyssal hills and abyssal plains (Cormier and Sloan, 2018). Near the trench the oceanic crust and overlying sediments are affected by normal faults caused by the bending of the plate by subduction (Kukowski et al., 2008). The SW Nazca Ridge shows numerous volcanic mounds and seamounts (Figs. 2a inset $\beta$ and 2b). Towards the northeast, the seafloor

159 of the Nazca Ridge shows fewer bathymetric highs related to volcanic features compared to

160 the southwestern part (Fig. 2b; Hampel et al., 2004). The Nazca Ridge shows the seafloor 161 geomorphology of an oceanic plateau (Harris et al., 2004; Fig. 2b), is narrow in the SW (156 $\mathrm{km})$ and wider towards the northeast (296 km). The seafloor is smoother in the same direction (Figs. 2a - inset $\gamma$, and 2b). The smooth seafloor is affected by incisions that are perpendicular

164 to the Nazca Ridge axis (Fig. 2a, inset $\gamma$ ) and that mark abyssal erosion linked to bottom 
Nazca Drift System - SE Pacific Ocean paleoceanography /doi:10.1017/S0016756821000960

165

166

currents (Lonsdale, 1976; Land et al., 1999; Gomes and Viana, 2002; Dubois and Mitchell, 2012; Mitchell and Huthnance, 2013; Rebesco et al., 2014; Juan et al., 2018). The relative importance of physical erosion and carbonate dissolution below the carbonate compensation depth (CCD) cannot be clearly resolved (Lonsdale, 1976).

\section{3.b Seismic facies}

Two main seismic facies classes are observed within the study area. The first class comprise reflectors interpreted as volcanic features, such as volcanic mounds, volcanic sills and the oceanic basement itself (Fig. 3). The second class is interpreted as deep-water sedimentary facies linked to the bottom currents observed to flow along the upper slopes of seamounts towards abyssal basins (Fig. 3).

The oceanic basement facies is encompassed by a single high amplitude reflection with minor to major offset related to faults (Fig. 3). This regional facies is locally affected by topographic highs that are associated with volcanic mounds (Fig. 3). The mounds have a variety of heights and slopes with steep or steepened flanks. These volcanic mounds have very low amplitude chaotic internal facies with rare high amplitude reflections. Most of these mounds are partially or completely buried under the concordant to onlapping parallel seismic facies described below. A cross-cutting high amplitude facies is present in the sedimentary cover above the acoustic basement. This high amplitude, saucer-shaped facies is interpreted to be indicative of volcanic sills (Fig. 3). The other observed facies are all within the seismic sequence spanning between the acoustic basement/oceanic crust and the seafloor. The most extensive facies developed regionally above the oceanic crust is the sheeted-abyssal drift (Figs. 3 and 4) that is characterized by parallel-concordant low to high amplitude reflections. The drift is mainly present in the two oceanic basins of Peru and Chile and in the Peru-Chile Trench where it is cut by faults (Fig. 4a). This facies was drilled at DSDP Site 321/ODP Site 1231 in the northern Peru Basin (Fig. 1) where it was found to comprise fine grained sediments, such as hemipelagic clay rich in siliceous fossils, discrete tephra horizons and dispersed volcanic ash, 
Nazca Drift System - SE Pacific Ocean paleoceanography /doi:10.1017/S0016756821000960

191

192

193

194

195

196

197

198

199

200

201

202

203

204

205

206

207

208

209

210

211

212

213

214

215

as well as nannofossil ooze interbedded with iron-rich nannofossil ooze (Shipboard Scientific Party, 1976 and 2003b).

Four other facies are observed in shallower layers of the SE Pacific Ocean. The first has low amplitude reflections in seismic data, with edges marked by a moat and wavy to parallel reflections. This facies is typical of a plastered drift (Fig. 3; e.g. Faugères et al., 1999) and is mainly observed on the edge of the Nazca Ridge (Fig. 4b and 4c). On the edge of some volcanic mounds, this facies has a mounded morphology, with low internal amplitudes that show an aggrading stack towards the flank of the topographic highs and thinning towards the external part of the mound. Parallel reflections are observed at the base of the mound and wavy reflections towards its upper surface. A small depression is observed along the contact of the mound edge with the lower structure it is supported by. This feature is associated with a moat (Fig. 3). These mounded features, isolated from the main feature (separated), showing basal termination that are onlap or downlap and when aside of a bathymetric high shows a depressed upper surface ('moat' or contourite channel), is aggrading, and shows upslope migration. Therefore, so based on Faugères et al (1999), it is then awe interpret this as a mounded separated/isolated drift. Where two topographic/basement highs are present, mounded features with low to high amplitude, parallel to wavy internal reflection, are observed with moats in seismic data at their edges. These types of structures are typical of a confined drift (Fig. 3; e.g. Faugères et al., 1999; Bailey et al., 2021). The thickest and most extensive facies is typical of mounded-wedge sediments with low seismic amplitude, a moat along the edge of the mound and with parallel to subparallel internal reflections. This facies is identified as a fault/scarp-controlled drift (Fig. 3; e.g. Rebesco and Stow, 2001 and references within) and is present from the Nazca Ridge top to the edge of the ridge (Fig. 4). This facies transitions away from the ridge into thinner bedded facies such as the sheeted abyssal drift (Fig. 4). In the following section the facies related to bottom currents are identified on a 
Nazca Drift System - SE Pacific Ocean paleoceanography /doi:10.1017/S0016756821000960

regional section (Figs. 4a, b and c) and combined with a thickness map of the sedimentary pile to define the Nazca Drift System (Fig. 4d).

\section{3.c Nazca Drift System}

Various seismic facies are observed within the complete sedimentary column between the top of the oceanic crust and/or Nazca Ridge (top basement) and the seafloor (Figs. 4a-c). The Nazca Drift System extends over the whole study area, with thickness varying from ca.104 to $375 \mathrm{~m}$ (Fig. 4d). Within this sequence the main depocenter is located in the northeast part of the Nazca Ridge (north of $18^{\circ} \mathrm{S}$ ) and extends from SW to NE (Figs. 4a and 4d), reaching a maximum thickness in the Peru-Chile Trench. From the Nazca Fracture Zone to the Peru Basin, the sequence thickens above the Nazca Ridge (Figs. 4b and d). The minimum thickness of this sequence is observed in the northern part of the Peru Basin (Figs. 4c and d). Locally the sequence is very thin, especially on the slopes of seamounts and volcanic mounds (Figs. 4a, b and c). The oceanic crust in the study area spans an age of $45 \mathrm{Ma}$ on the edge of the Peru-Chile Trench to younger than 32 Ma southwest of the Nazca Ridge (Hampel, 2002; Müller et al., 2008). At ODP Site 1237 the oldest strata cored are Oligocene, with an age of ca.31 Ma (Shipboard Scientific Party, 2003; King and Wade, 2017). The basement was not reached at that location.

We interpret the Nazca Drift System based on the occurrence of facies related to bottom currents, the thickness of the entire sequence and seafloor geometry. Its southwest extent is presently not well defined because of the absence of regional seismic profiles in this part of the study area. Confined drift facies between and along the slopes of volcanic mounds in the southwest of the study area are observed at ODP Site 1236, but we have decided to limit the Nazca Drift System northwest of this area because a connection is not possible to establish at present because of the barrier created by the seamount southwest of the Nazca Ridge (Figs. 4a, and 4d). The Nazca Drift System is pear-shaped in plan-view, with its widest part located at the Peru-Chile Trench (Fig. 4d). The facies mapped along the three regional cross sections (Fig. 4a-c) show the dominant types related to extensive fault scarp-controlled drift 
Nazca Drift System - SE Pacific Ocean paleoceanography /doi:10.1017/S0016756821000960

sedimentation. In transition to the sheeted abyssal drift facies in the abyssal deepest part of the oceanic bounding basins, plastered drift facies are observed on slopes on both side of the Nazca Ridge (Figs. 4b and 4c).

The Nazca Drift System presently sits in water depths of 2,090-5,330 m (Fig. 5a). Erosional surfaces at the seafloor marked by toplaps and erosional truncations are observed on 2D seismic profiles at water depths of ca.2,200-4,095 m (Fig. 5b). This range of water depths leaves most of the upper surface of the Nazca Drift System exposed to the present day Pacific Central Water (PCW) and Circumpolar Deepwater (CDW) (Fig. 5c). The asymmetric thickness of the Nazca Drift System, i.e. thinner in the Chile Basin compared to the Peru Basin, could be explained by northward movement of the CDW (Lonsdale, 1976). The Nazca Drift System covers an area of 204,500 $\mathrm{km}^{2}$. It represents the largest yet identified abyssal drift system in the Pacific Ocean. Globally it is only surpassed by the Zapiola Drift in the western South Atlantic and the Mozambique Channel contourite in the Indian Ocean (Flood and Shor, 1988; Kolla et al., 1980; Rebesco et al., 2014). The volume of this giant sedimentary body is ca.51,445 $\pm 5,715 \mathrm{~km}^{3}$ (Fig. 4d). If the Nazca Drift System is no older than Oligocene, the average long-term accumulation rate is $0.7 \pm 0.08 \mathrm{~km}^{3} / \mathrm{ky}$.

\section{3.d Chronological framework}

Unconformities are observed at the seafloor and within the subsurface of the Nazca Drift System (Figs. 5b and 6). The seafloor is affected by erosion and the underlying PlioPleistocene strata are also marked by erosional truncation at various water depths (Figs. 5b and 6). The seafloor water depth at which the transition from southward migrating PCW and northward migrating CPW occurs is correlative of these erosional truncations (Fig. 4b). These erosive surfaces in the northeast part of the Nazca Drift System have scoured geometries, with orientations suggesting they were produced by SE to NW flow (Figs. 2 and 6). These subsurface unconformities are localized in areas where the sedimentary section is draping fault scarps that offset the basement and have significant heave (>125 ms TWT). The projected ages measured at ODP Site 1237 allows calibration of the duration of the oldest 
Nazca Drift System - SE Pacific Ocean paleoceanography /doi:10.1017/S0016756821000960

270

271

272

273

274

275

276

277

unconformities observed in the southeast part of the drift (Fig. 6a-b). The older age is estimated at the depth of the mid to upper Miocene and the youngest sediment above this truncation is associated to the intra upper Miocene. The top of the unconformity is bracketed in a depth of 149-170 m below seafloor, based on P wave velocity ranging 1,600-1,800 m/s. The youngest calibrated age from the shipboard age model of ODP Site 1237 is from ca.7.7 to 9.4 Ma (Shipboard Scientific Party, 2003).

The unconformities do not seem to be associated to mass wasting because there is no scarp up-dip or chaotic/transparent seismic facies diagnostic of mass transport deposits identified down slope. The high carbonate content of sediment described at ODP Site 1237 excludes strong dissolution as a cause of the unconformities due to sedimentation below the CCD (Berger, 1978; Berger et al., 1982), thus making the erosional truncations likely to have been caused by remobilization of the exposed parts of the Nazca Drift System because of intense bottom current scouring, potentially active over long periods of time (Southard et al., 1971). No bottom current velocity has been measured at the Nazca Ridge, but instead further north at the Carnegie Ridge (Lonsdale \& Malfait; 1974) and south of it in the Chile Basin (Shaffer et al., 1995; 2004), where bottom water is flowing at mean speeds from 3 to $7.8 \mathrm{~cm} / \mathrm{s}$. Lonsdale (1976) suggested the presence of rather slow currents east and west of the Nazca Ridge, in the sill and trench where water moving from the Chile to the Peru Basin is flowing at depths deeper than the adiabatic bottom layer. Furthermore, the measured tidal currents (15-20 cm/s) at the Carnegie Ridge are superimposed with slow speed drift $(3 \mathrm{~cm} / \mathrm{s})$. This abyssal tidal current is effective at driving erosion of fine particles (Lonsdale \& Malfait, 1974). By analogy with the Carnegie Ridge the study area would be prone to being influenced by the same processes, tidal forcing and strong bottom currents, causing erosion at the seafloor surface. Experimental erosion of calcareous ooze by currents showed that the critical speed for erosion to start is ca.7-10 cm/sec (Southard et al., 1971), thus corresponding to the observed values of near bottom currents in the SE Pacific. 
Nazca Drift System - SE Pacific Ocean paleoceanography /doi:10.1017/S0016756821000960

\section{Discussion}

4.a Initiation of the Nazca Drift System in the regional oceanic gateways framework The Nazca Drift System extends from the SW of the Nazca Ridge to the Peru-Chile Trench

(Fig. 4). The eastward motion of the Nazca Plate since the emplacement of the drift is well constrained (e.g. Hampel, 2002). Before the Nazca Ridge reached the trench normal, lowrelief oceanic crust was subducting. The trench-slope of South America and the oceanic barrier formed by the Nazca Ridge against bottom waters moving from the Southern Ocean to the equatorial domain results in a funnel for sediment transport. The oldest sediments cored at ODP Site 1237 (ca.31 Ma, King and Wade, 2017) indicate carbonate sedimentation until 15 Ma (Fig. 7a). The basement was not reached by drilling at ODP Site 1237 but the sediment column between the total drilled depth and the acoustic basement is thin (0.016 s TWT ca.15 m; Fig. 6), implying a maximum age of ca.36.8 Ma at the base (sedimentation rate of 2.55 m/m.y.; King and Wade, 2017), which is younger than the initiation of the opening of the Drake Passage (41 Ma; Scher and Martin, 2006). The initiation of the Nazca Drift System could be related to the opening of the Drake Passage and the northward branch bifurcation of the ACC along the Pacific margin of South America.

Productivity of the main fraction of the sediments comprising the Nazca Drift System is related to water masses and current evolution. As a result the sedimentation rate should also partly reflect the signal of the current intensity, as well as sediment supply rate. The clastic input is the result of the proximity of the ridge to terrestrial sources, mainly dust - eolian siliciclastic, while migrating towards South America (Tiedemann and Mix, 2007). The averaged 1 Myr sedimentation rate at OPD Site 1237 (Fig. 7a) in the eastern portion of the Nazca Drift System increased during the period when the discontinuity is recorded 9.4-7.0 Ma. The thickness of the drift is higher to the north of the unconformity (Fig. 6) because the bottom current related to the CPW sweeps sediments towards ODP Site 1237. About $70 \%$ of the Nazca Drift System is above the CCD at present day (Figs. 4 and 5c). Reconstructions based on a typical oceanic subsidence curve (Stein and Stein, 1992) indicate that ODP Site 
Nazca Drift System - SE Pacific Ocean paleoceanography /doi:10.1017/S0016756821000960

1237 on the Nazca Ridge would have been above the regional CCD until 21.7 Ma (Fig. 7, Rea and Leinen, 1985; Pälike et al., 2012). DSDP Site 321 in the abyssal Peru Basin north of the study area descended below the CCD after 24 Ma (Fig. 7b, Rea and Leinen, 1995). ODP Site 1237 is shallower and crossed the CCD during the early Miocene. The $\mathrm{CaCO}_{3}$ mass accumulation rates had been stable for over ca. 2 m.y. before decreasing after $20 \mathrm{Ma}$ and increasing towards the end of the middle Miocene at ca.12 Ma (Figs. 7a-b). This framework excludes a major role for carbonate dissolution in the generation of unconformities within or above the Nazca Drift System. The CCD could have been locally depressed by high deposition rates, as observed at the equator (Pälike et al., 2012).

\section{4.b Intensity of bottom water flow and building the Nazca Drift System}

The thickness variation and identification of internal and superficial unconformities within the Nazca Drift System shows that bottom water currents have played a key role in the evolution of the sedimentary record in this part of the Pacific Ocean.

Framed within the last 30 m.y., the study area has been under the influence of Southern Ocean evolution, as well as solid earth and hydrosphere interaction (e.g. Scher et al., 2015; Wright et al., 2016) (Fig. 7c). Similar to the Eastern New Zealand Oceanic Sedimentary System which is made of abyssal drift deposits (Carter et al., 1996), the Nazca Drift System has been emplaced in an abyssal domain since the Oligocene under the influence of the AAC and the associated Circumpolar Deepwater (CDW). The oldest sequences drilled at ODP Site 1237 record alternating fine-scale variation and changes in sedimentation rates that started with the lowest rate operating over periods of ca. 3.6 m.y. and higher rate during shorter periods of 1.6 m.y. (King and Wade, 2017). These changing rates could reflect the intensity of productivity and or variation in the intensity of bottom currents.

A widespread erosional event associated with the establishment of the ACC and the Deep Western Boundary Current (DBWC) has been identified in the record of the Bounty Trough SW Pacific Ocean (Horn and Uenzelmann-Neben, 2015). A major ca.5 m.y. hiatus separates the middle Miocene ca.10.4 Ma from the lower Pliocene at ODP Site 1122 (Shipboard 
Nazca Drift System - SE Pacific Ocean paleoceanography /doi:10.1017/S0016756821000960

351 Scientific Party, 1999; Carter et al., 1999). This erosional event correlates with the

intensification caused by a more vigorous ACC, synchronous with the build-up of the West

353 Antarctic Ice Sheet (Carter et al., 2004). In the Drake Passage, the identified South Falkland

354 Slope Drift also contains unconformities of the same age, ca.9 Ma (Koenitz et al., 2008). The

355 thickness of the drift is a function of the evolution of sediment supply and current intensity.

356 High sedimentation rates in the early Miocene were followed by a decreasing rate during the

357 late Miocene to Pleistocene period. The identified unconformity within the Nazca Drift

358 System is dated within this middle Miocene period of intensified bottom currents, ca.7.7-9.4

359 Ma. We therefore attribute this unconformity to the same process. Geochemical analyses at

360 ODP Site 1237 show a change in nutrient burial preservation from oxygenated to more

361 reduced conditions at ca.162 mcd (8.8 Ma; Chun and Delaney, 2006). This change

362 corresponds to the depth at which the late Miocene unconformity was identified on seismic

363 reflection profiles and could be attributed to bottom water chemistry and currents' variations

364 in this part of the SE Pacific Ocean. The ACC strength has been documented further south,

365 with initiation dated to have occurred during the late Oligocene to late Miocene (Lyle et al.,

366 2007).

367 4.c Tectonic and contourite drift in the subduction channel

368 A significant part of the Nazca Ridge has been subducted since at least the end of the middle

369 Miocene ca.11.2 Ma (Hampel, 2002). Because ridge construction and the sedimentary drift

370 accumulation are older than the initiation of Nazca Ridge subduction, a potentially large

371 volume of deep sea sediments and polymetallic accumulations could have contributed to

372 orogenesis and mineralization in the Andes.

373 Water is widely recognized to be a key ingredient in the generation of magmas in subduction

374 zones, making these zones efficient carbon burial (Grove et al., 2012; Plank and Manning,

375 2019). Geodynamic reconstructions indicate that metallogenic activity has followed the

376 southward movement of the Nazca Ridge along the coast of South America (Rosenbaum et

377 al., 2005). This migration is associated with an increase in emplacement of $\mathrm{Cu}, \mathrm{Au}$ and $\mathrm{Zn}$ 
Nazca Drift System - SE Pacific Ocean paleoceanography /doi:10.1017/S0016756821000960

deposits from 8 to 6 Ma (Rosenbaum et al., 2005). The area of the Nazca Ridge subducted since 11.2 Ma is estimated to represent a surface of ca. $420 \times 10^{3} \mathrm{~km}^{2}$. This subducted part of the plate was covered by sediments, similar to the remaining western part of the Nazca Ridge. We estimate, based on the present day thickness of Oligocene-middle Miocene strata (Figure 6A, 0.225 sTWT) that the maximum subducted sediment thickness was 180-200 m. This results in a figure of $80 \pm 5 \times 10^{3} \mathrm{~km}^{3}$ of sediments that may have contributed to Andean mineral evolution. The porosity of this sedimentary sequence can be high at 60-90 \% (Velde, 1996; D'Hondt et al., 2003; Yu et al., 2020), leading to a higher than normal amount of water entering the subduction channel (Bray and Karig, 1985), especially considering that subduction of Nazca Ridge increased subduction erosion along the Andean margin, adding even more sediment and water from any pre-existing accretionary prism. This higher volume of water at the Nazca Ridge could have increased the amount of melting.

\section{Conclusions}

Based on seafloor bathymetry, seismic reflection data and scientific drilling sites, we can draw the following conclusions:

(a) The Nazca Drift System has been identified in the SE Pacific Ocean. The Nazca Drift System spans from the Chile Basin, across the Nazca Ridge into to the Peru Basin,

(b) this major paleoceanographic sedimentary feature of the SE Pacific Ocean accumulated on top of the Nazca Ridge since the Oligocene,

(c) the Nazca Drift System represents the largest identified abyssal drift system yet in the Pacific Ocean,

(d) the main present-day bottom currents winnowing the seafloor sediments of the Nazca Drift System are related to the Pacific Central Water (PCW) and Circumpolar Deepwater (CDW),

the initiation of the Nazca Drift System could be related to the opening of the Drake Passage and the northward branch bifurcation of the ACC along the Pacific margin of South America, 
Nazca Drift System - SE Pacific Ocean paleoceanography /doi:10.1017/S0016756821000960

(e) the currents have been sculpting this giant sedimentary body experienced fluctuating intensities as recorded by internal unconformities identified by acoustic discontinuities. The calibrated age of the oldest unconformity in the SE part of the Nazca Drift System is Late Miocene (Tortonian) and can be correlated to the change of bottom water conditions recorded at ODP Site 1237 from oxygenated to more reduced conditions. Evidence of younger discontinuities shows that the bottom currents have been varying in response to southern hemisphere climatic change and the eastward motion of the Nazca Plate,

and a significant part of the Nazca Drift System that has already subducted has contributed to the subduction channel. This spatially is further related onshore to subduction magmatism and mineralization, as well as the Andean orogenic cycle since the Late Miocene (ca.11.2 Ma).

Further analyses such as grain size and geochemistry should be able to constrain the paleo bottom-current intensity, variation and the detailed emplacement of this sedimentary drift. Future studies comparing these findings to drift systems occurring along other deep-water fold and thrust belts in active margins will lead to an increasing number of new drift system provinces.

\section{Acknowledgements:}

This research used data provided by the International Ocean Discovery Program (IODP).

GENEO3RR subsurface data were accessed by the Site Survey Data Bank (SSDB, https://ssdb.iodp.org/index.php). Cecily Pälike (MARUM) and Peggy Delaney (UCSC) are thanked for discussion regarding the geochemistry of sediments at Site 1237. Andrea Hampel (Leibniz Universität Hannover) for access to the velocity data from SO146-GEOPECO cruise. Paul Henkart is thanked for help with the single channel data. NOAA-NCEI for the Multibeam Bathymetry data base (https://www.ngdc.noaa.gov/maps/autogrid/). IHS-Kingdom is thanked for their Software University Grants that have allowed this work to take place. 
commenting on an earlier version of our manuscript. Reviews from the editor Stephen

433 Hubbard, and reviews from W. Bailey, M. Cason, F. J. Hernandez-Molina and an anonymous

reviewer greatly helped to clarify our work.

435

436

437

438

439

440

441

442

443

444

445

446

447

448

449

450

451

452

453

454

455

456

457

458

459

460

461

462

463

464

465

466

467

468

469

470

471

472

473

474

475

476

477

478

\section{Conflict of Interest:}

The authors declare that they have no conflict of interest.

\section{Figures:}

Figure 1: (Colour online) (a) Bathymetry and topography of the SE Pacific locating the Nazca Drift System with a blue outline (black lines; data from: single channel seismic lines from Marine Geoscience Data System, www.marine-geo.org; R/V Sonne cruise SO146-GEOPECO (green lines; Hampel et al., 2004) and GENEO3RR (orange lines; Mix, 1997)). Sonobuoy data C13-30 and C13-32 are located near ODP Site 1237 (Diebold, 1996). Arrows indicate general flow directions of surface currents (black short dots bold line; PCC: Peru Coastal Current; POC: Peru Oceanic Current) and subsurface currents (black long dots bold line; PCCC: Peru-Chile Countercurrent; CPDCC: Chile-Peru Deep Coastal Current; PCUC: PeruChile Undercurrent) (e.g., Chaigneau et al., 2013) along the Peru-Chile margin. Drilling sites are from DSDP and ODP Legs 112, 138 and 202 (Shipboard Scientific Party, 1988; 1992; 2003a). STRATUS mooring is located west of the study area (https://www.pmel.noaa.gov/co2/story/Stratus). (b) Temperature-salinity diagram at CTD station 7546483(C) (Yellow triangle in Figure 1A; $15.373^{\circ} \mathrm{S} ; 76.751^{\circ} \mathrm{W}$ ), (C) Hydrographic section of the SE Pacific sector, oxygen concentrations showing major water masses and boundaries. AAIW: Antarctic Intermediate Water; CDW: Circumpolar Deep Water; ESPIW: South Pacific Intermediate Water; ESSW: Equatorial Subsurface Water. Ridges: Sala y Gomes Ridge (SyGR), Nazca Ridge (NR) Carnegie Ridge (CR).

Figure 2: (Colour online) Seafloor bathymetry and geomorphology of the Nazca Drift System and the surrounding basins. (a) Multibeam (in color, NOAA-NCEI; https://www.ngdc.noaa.gov/maps/autogrid/) and GEBCO (gray scale; https://www.gebco.net/data_and_products/gridded_bathymetry_data/) bathymetry of the study area. Insets: examples of three different seafloor geomorphologies: $(\alpha)$ faulted oceanic crust, $(\beta)$ volcanic seamount, and $(\gamma)$ smooth seafloor/drift (CI: contour interval). (b) Seafloor typology from interpretation of Harris et al. (2014).

Figure 3: (Colour online) Seismic facies observed in the study area between the acoustic basement (top basement: TB) and the seafloor. Two main seismic facies classes: volcanics and sedimentary, are observed within the study area and interpreted based on Calvès et al. (2011) and Dubois and Mitchell (2012) and Rebesco et al. (2014), respectively. TWT: twoway time.

Figure 4: (Colour online) Regional line drawing of seismic reflection lines (single channel seismic: SCS, LDEO) across the Nazca Ridge and the Nazca Drift System. (a) From seamount SW of Nazca Ridge to the Peru-Chile Trench (SW-NE). (b) From Peru Basin across the Nazca Ridge to the Chile Basin and the Nazca Fracture Zone (NW-SE). (c) From the Peru Basin to the Chile basin and Peru-Chile Trench (W-E). D. Isopach map of megasequence above acoustic basement.

Figure 5: (Colour online) Hypsometry of Nazca Drift System present day drift with paleoceanography framework and present day water masses. (a) Scatter plot of Nazca Drift System thickness as a function of water depth, (b) Nazca Drift System erosional truncation relative frequency by water depth range, and (c) Nazca Drift System water depth relative frequency. Present day, paleo carbonate compensation depth (CCD) and lysocline in the South Pacific Ocean (Rea and Leinen, 1985). Pacific Central Water (PCW) and Circumpolar 
Deepwater (CDW) (Tsuchiya and Talley, 1998). Depths of DSDP and ODP sites are present day water depth at each site (Shipboard Scientific Party, 1976, 2003a).

Figure 6: (Colour online) Eastern Nazca Drift System seismic framework. (a) WSW-ENE seismic profile across ODP Site 1237 with stratigraphy (Shipboard Scientific Party, 2003a), (b) NW-SSE seismic profile from the Nazca Ridge to the Chile Basin, and (c) SW-NE seismic profile along the long axis of the Nazca Ridge with volcanic mounds and varying thickness of the Nazca Drift System. Note the volcanic sill intruding the Nazca Drift System. Location map of the profiles is in the bathymetry inset map. Water masses and currents directions are layered above the acoustic seafloor. Pacific Central Water (PCW) and Circumpolar Deepwater (CDW) (Tsuchiya and Talley, 1998).

Figure 7: (Colour online) (a) Sedimentation rate at ODP Site 1237 (Shipboard Scientific Party, 2003a) and (b) Subsidence at three DSDP and ODP sites with CCD and lysocline depths over the last 40 m.y. in two domains of the Pacific Ocean (Rea and Leinen, 1985; Pälike et al., 2012). (c) Paleoceanography, geodynamic and climatic context sourced from Zachos et al. (2001), Lamb and Davies (2003), and Scher and Martin (2006).

\section{Supplementary Material}

Figure S1: uninterpreted and interpreted single-channel seismic data related to Figure 4. Data source: https://www.ngdc.noaa.gov/mgg/seismicreflection/index.html

Figure S2: uninterpreted seismic data related to Figure 6. Data source: IODP Site Survey Data Bank, https://ssdb.iodp.org/index.php

\section{References}

BAILEY, W.S., MCARTHUR, A.D., \& MCCAFFREY, W.D. (2021). Distribution of contourite drifts on convergent margins: examples from the Hikurangi subduction margin of New Zealand. Sedimentology 1-26. doi:10.1111/sed.12779

BARKER, P. F., FILIPPELLI, G. M., FLORINDO, F., MARTIN, E. E., \& SCHER, H. D. (2007). Onset and role of the Antarctic Circumpolar Current. Deep Sea Research Part II: Topical Studies in Oceanography, 54(21), 2388-2398. doi:10.1016/j.dsr2.2007.07.028

BERGER, W. H. (1978). Sedimentation of deep-sea carbonate; maps and models of variations and fluctuations. Journal of Foraminiferal Research, 8(4), 286-302. https://doi.org/10.2113/gsjfr.8.4.286

BERGER, W.H., BONNEAU, M.-C., \& PARKER, F.L. (1982). Foraminifera on the deep-sea floor: lysocline and dissolution rate. Oceanologica Acta 5, 249-258.

BOYER, T.P., ANTONOV, J.I., BARANOVA, O.K., COLEMAN, C., GARCIA, H.E., GRODSKY, A., JOHNSON, D.R., LOCARNINI, R.A., MISHONOV, A.V., O'BRIEN, T.D., PAVER, C.R., REAGAN, J.R., SEIDOV, D., SMOLYAR, I.V., \& ZWENG, M.M. (2013). World Ocean Database 2013, NOAA Atlas NESDIS 72. Levitus, S. (Ed.), Mishonov, A. (Technical Ed.). Silver Spring, M.D., 209 pp. https://doiorg.insu.bib.cnrs.fr/10.7289/V5NZ85MT.

BRAY, C. J., \& KARIG, D. E. (1985). Porosity of sediments in accretionary prisms and some implications for dewatering processes. Journal of Geophysical Research: Solid Earth, 90(B1), 768-778. https://doi.org/10.1029/JB090iB01p00768

CALVÈS, G., SCHWAB, A. M., HUUSE, M., CLIFT, P. D., GAINA, C., JOLLEY, D., TABREZ, A.R., \& INAM, A. (2011). Seismic volcanostratigraphy of the western Indian 
Nazca Drift System - SE Pacific Ocean paleoceanography /doi:10.1017/S0016756821000960

rifted margin: The pre-Deccan igneous province. Journal of Geophysical Research, 116(B1), B01101. doi:10.1029/2010JB000862

CALVÈS, G., AUGUY, C., DE LAVAISSIÈRE, L., BRUSSET, S., CALDERON, Y., \& BABY, P. (2017). Fore-arc seafloor unconformities and geology: Insight from 3-D seismic geomorphology analysis, Peru. Geochemistry, Geophysics, Geosystems, 18(8), 3062-3077. doi:10.1002/2017GC007036

CARTER, L., CARTER, R. M., MCCAVE, I. N., \& GAMBLE, J. (1996). Regional sediment recycling in the abyssal Southwest Pacific Ocean. Geology, 24(8), 735-738. doi:10.1130/0091-7613(1996)024<0735:RSRITA>2.3.CO;2

CARTER, R.M., MCCAVE, I.N., RICHTER, C., CARTER, L., ET AL. (1999). Proc. ODP, Init. Repts., 181: College Station, TX (Ocean Drilling Program). doi:10.2973/odp.proc.ir.181.2000

CARTER, L., CARTER, R. M., \& MCCAVE, I. N. (2004). Evolution of the sedimentary system beneath the deep Pacific inflow off eastern New Zealand. Marine Geology, 205(1), 9-27. doi:10.1016/S0025-3227(04)00016-7

CASALBORE, D. (2018). Volcanic Islands and Seamounts - Submarine Geomorphology. In A. Micallef, S. Krastel, \& A. Savini (Eds.) (pp. 333-347). Cham: Springer International Publishing. doi:10.1007/978-3-319-57852-1_17

CHAIGNEAU, A., DOMINGUEZ, N., ELDIN, G., VASQUEZ, L., FLORES, R., GRADOS, C., \& ECHEVIN, V. (2013). Near-coastal circulation in the Northern Humboldt Current System from shipboard ADCP data. Journal of Geophysical Research: Oceans, 118(10), 5251-5266. doi:10.1002/jgrc.20328

CHUN, C.O.J., \& DELANEY, M.L. (2006). Phosphorus, barium, manganese, and uranium concentrations and geochemistry, Nazca Ridge Site 1237 sediments. In Tiedemann, R., Mix, A.C., Richter, C., and Ruddiman, W.F. (Eds.), Proc. ODP, Sci. Results, 202: College Station, TX (Ocean Drilling Program), 1-19. doi:10.2973/odp.proc.sr.202.205.2006

CLIFT, P. D., PECHER, I., KUKOWSKI, N., \& HAMPEL, A. (2003). Tectonic erosion of the Peruvian forearc, Lima Basin, by subduction and Nazca Ridge collision. Tectonics, 22(3), 1023, doi:10.1029/2002TC001386

CORMIER, M.-H., \& SLOAN, H. (2018). Abyssal Hills and Abyssal Plains BT - Submarine Geomorphology. In A. Micallef, S. Krastel, \& A. Savini (Eds.) (pp. 389-408). Cham: Springer International Publishing. doi:10.1007/978-3-319-57852-1_20

D'HONDT, S.L., JØRGENSEN, B.B., MILLER, D.J., ET AL. (2003). Proc. ODP, Init. Repts., 201: College Station, TX (Ocean Drilling Program). doi:10.2973/odp.proc.ir.201.2003

DIEBOLD, J.B. (1996). Data table: sediment and crustal velocities from sonobuoy solutions. Accessed from Geomapapp.org, 2019 
Nazca Drift System - SE Pacific Ocean paleoceanography /doi:10.1017/S0016756821000960

DUBOIS, N., \& MITCHELL, N. C. (2012). Large-scale sediment redistribution on the equatorial Pacific seafloor. Deep Sea Research Part I: Oceanographic Research Papers, 69, 51-61, doi:10.1016/j.dsr.2012.07.006

DUTKIEWICZ, A., MÜLLER, R. D., O’CALLAGHAN, S., \& JÓNASSON, H. (2015). Census of seafloor sediments in the world's ocean. Geology, 43(9), 795-798. doi:10.1130/G36883.1

EMERY, W.J., \& MEINCKE, J. (1986). Global water masses: Summary and review. Oceanologica Acta 9(4).

EMERY, W. J. (2019). Water Types and Water Masses. In J. K. Cochran, H. J. Bokuniewicz, \& P. L. B. T.-E. of O. S. (Third E. Yager (Eds.) (pp. 169-179). Oxford: Academic Press. https://doi.org/https://doi.org/10.1016/B978-0-12-409548-9.04426-2

ESENTIA, I., STOW, D., \& SMILLIE, Z. (2018). Contourite Drifts and Associated Bedforms. In A. Micallef, S. Krastel, \& A. Savini (Eds.), Submarine Geomorphology (pp. 301-331). Cham: Springer International Publishing. doi:10.1007/978-3-319-57852-1_16

ESPURT, N., BABY, P., BRUSSET, S., RODDAZ, M., HERMOZA, W., REGARD, V., ANTOINE, P.-O., SALAS-GISMONDI, R., \& BOLAÑOS, R. (2007). How does the Nazca Ridge subduction influence the modern Amazonian foreland basin? Geology, 35(6), 515-518. doi:10.1130/G23237A.1

FAUGÈRES, J.-C., STOW, D. A., IMBERT, P., \& VIANA, A. (1999). Seismic features diagnostic of contourite drifts. Marine Geology, 162(1), 1-38. doi:10.1016/S00253227(99)00068-7

FLOOD, R. D., \& SHOR, A. N. (1988). Mud waves in the Argentine Basin and their relationship to regional bottom circulation patterns. Deep Sea Research Part A. Oceanographic Research Papers, 35(6), 943-971. doi:10.1016/0198-0149(88)90070-2

GEBCO Compilation Group (2019). GEBCO 2019 Grid, doi:10.5285/836f016a-33be-6ddce053-6c86abc0788e

GOMES, P. O., \& VIANA, A. R. (2002). Contour currents, sediment drifts and abyssal erosion on the northeastern continental margin off Brazil. Geological Society, London, Memoirs , 22(1), 239-248. doi:10.1144/GSL.MEM.2002.022.01.17

GROVE, T. L., TILL, C. B., \& KRAWCZYNSKI, M. J. (2012). The Role of H2O in Subduction Zone Magmatism. Annual Review of Earth and Planetary Sciences, 40(1), 413-439. https://doi.org/10.1146/annurev-earth-042711-105310

HAMPEL, A. (2002). The migration history of the Nazca Ridge along the Peruvian active margin: a re-evaluation. Earth and Planetary Science Letters, 203(2), 665-679. doi:10.1016/S0012-821X(02)00859-2

HAMPEL, A., KUKOWSKI, N., BIALAS, J., HUEBSCHER, C., \& HEINBOCKEL, R. (2004). Ridge subduction at an erosive margin: The collision zone of the Nazca Ridge in southern Peru. Journal of Geophysical Research: Solid Earth, 109(B2). doi:10.1029/2003JB002593 
Nazca Drift System - SE Pacific Ocean paleoceanography /doi:10.1017/S0016756821000960

HARRIS, P. T., \& MACMILLAN-LAWLER, M. (2018). Origin and Geomorphic Characteristics of Ocean Basins. In A. Micallef, S. Krastel, \& A. Savini (Eds.), Submarine Geomorphology (pp. 111-134). Cham: Springer International Publishing. doi:10.1007/978-3-319-57852-1_8

HARRIS, P. T., MACMILLAN-LAWLER, M., RUPP, J., \& BAKER, E. K. (2014). Geomorphology of the oceans. Marine Geology, 352, 4-24. doi:10.1016/j.margeo.2014.01.011

HORN, M., \& UENZELMANN-NEBEN, G. (2015). The Deep Western Boundary Current at the Bounty Trough, east of New Zealand: Indications for its activity already before the opening of the Tasmanian Gateway. Marine Geology, 362, 60-75. doi:10.1016/j.margeo.2015.01.011

JOHNSON, G. C. (2008). Quantifying Antarctic Bottom Water and North Atlantic Deep Water volumes. Journal of Geophysical Research: Oceans, 113(C5). https://doi.org/10.1029/2007JC004477

JUAN, C., VAN ROOIJ, D., \& DE BRUYCKER, W. (2018). An assessment of bottom current controlled sedimentation in Pacific Ocean abyssal environments. Marine Geology, 403, 20-33. doi:10.1016/j.margeo.2018.05.001

KOENITZ, D., WHITE, N., MCCAVE, I. N., \& HOBBS, R. (2008). Internal structure of a contourite drift generated by the Antarctic Circumpolar Current. Geochemistry, Geophysics, Geosystems, 9(6), doi:10.1029/2007GC001799

KOLLA, V., EITTREIM, S., SULLIVAN, L., KOSTECKI, J. A., \& BURCKLE, L. H. (1980). Current-controlled, abyssal microtopography and sedimentation in Mozambique Basin, southwest Indian Ocean. Marine Geology, 34(3), 171-206. doi:10.1016/00253227(80)90071-7

KUKOWSKI, N., HAMPEL, A., HOTH, S., \& BIALAS, J. (2008). Morphotectonic and morphometric analysis of the Nazca plate and the adjacent offshore Peruvian continental slope - Implications for submarine landscape evolution. Marine Geology, 254(1), 107120. doi:10.1016/j.margeo.2008.05.017

LAMB, S., \& DAVIS, P. (2003). Cenozoic climate change as a possible cause for the rise of the Andes. Nature, 425, 792. Retrieved from http://dx.doi.org/10.1038/nature02049

LAND, L. A., PAULL, C. K., \& SPIESS, F. N. (1999). Abyssal erosion and scarp retreat: Deep Tow observations of the Blake Escarpment and Blake Spur. Marine Geology, 160(1), 63-83. doi:10.1016/S0025-3227(99)00012-2

LONSDALE, P., \& MALFAIT, B. (1974). Abyssal Dunes of Foraminiferal Sand on the Carnegie Ridge. GSA Bulletin, 85(11), 1697-1712. doi:10.1130/00167606(1974)85<1697:ADOFSO>2.0.CO;2

LONSDALE, P. (1976). Abyssal circulation of the southeastern Pacific and some geological implications. Journal of Geophysical Research (1896-1977), 81(6), 1163-1176. doi:10.1029/JC081i006p01163 
Nazca Drift System - SE Pacific Ocean paleoceanography /doi:10.1017/S0016756821000960

664

665

666

667

LYLE, M., GIBBS, S., MOORE, T. C., \& REA, D. K. (2007). Late Oligocene initiation of the Antarctic Circumpolar Current: Evidence from the South Pacific. Geology, 35(8), 691694. doi:10.1130/G23806A.1

MITCHELL, N. C., \& HUTHNANCE, J. M. (2013). Geomorphological and geochemical evidence (230Th anomalies) for cross-equatorial currents in the central Pacific. Deep Sea Research Part I: Oceanographic Research Papers, 78, $24-41$. https://doi.org/https://doi.org/10.1016/j.dsr.2013.04.003

MIX, A. (1997). Genesis Expedition LEG 3 (GENE03RR) R/V Revelle. Report and index of Underway Marine Geophysical Data.

MÜLLER, R.D., M. SDROLIAS, C. GAINA, \& W.R. ROEST (2008). Age, spreading rates and spreading symmetry of the world's ocean crust, Geochem. Geophys. Geosyst., 9, Q04006, doi:10.1029/2007GC001743.

PÄLIKE, H., LYLE, M. W., NISHI, H., RAFFI, I., RIDGWELL, A., GAMAGE, K., ... ZEEBE, R. E. (2012). A Cenozoic record of the equatorial Pacific carbonate compensation depth. Nature, 488, 609. doi:10.1038/nature11360

PILGER JR., R. H. (1981). Plate reconstructions, aseismic ridges, and low-angle subduction beneath the Andes. GSA Bulletin, 92(7), 448-456. doi:10.1130/00167606(1981)92<448:PRARAL>2.0.CO;2

PLANK, T., \& MANNING, C. E. (2019). Subducting carbon. Nature, 574(7778), 343-352.

REA, D. K., \& LEINEN, M. (1985). Neogene history of the calcite compensation depth and lysocline in the South Pacific Ocean. Nature, 316(6031), 805-807. doi:10.1038/316805a0

REBESCO, M., HERNÁNDEZ-MOLINA, F. J., VAN ROOIJ, D., \& WÅHLIN, A. (2014). Contourites and associated sediments controlled by deep-water circulation processes: State-of-the-art and future considerations. Marine Geology, 352, 111-154. doi:10.1016/j.margeo.2014.03.011

REBESCO, M., \& STOW, D. (2001). Seismic expression of contourites and related deposits: a preface. Marine Geophysical Researches, 22(5), 303-308. https://doi.org/10.1023/A:1016316913639

ROSENBAUM, G., GILES, D., SAXON, M., BETTS, P. G., WEINBERG, R. F., \& DUBOZ, C. (2005). Subduction of the Nazca Ridge and the Inca Plateau: Insights into the formation of ore deposits in Peru. Earth and Planetary Science Letters, 239(1), 18-32. doi:10.1016/j.epsl.2005.08.003

ROUSSE, S., GILDER, S., FARBER, D., MCNULTY, B., PATRIAT, P., TORRES, V., \& SEMPERE, T. (2003). Paleomagnetic tracking of mountain building in the Peruvian Andes since 10 Ma. Tectonics, 22(5). doi:10.1029/2003TC001508 
Nazca Drift System - SE Pacific Ocean paleoceanography /doi:10.1017/S0016756821000960

SCHER, H. D., \& MARTIN, E. E. (2006). Timing and Climatic Consequences of the Opening of Drake Passage. Science, 312(5772), 428 LP - 430. https://doi.org/10.1126/science.1120044

SCHER, H. D., WHITTAKER, J. M., WILLIAMS, S. E., LATIMER, J. C., KORDESCH, W. E. C., \& DELANEY, M. L. (2015). Onset of Antarctic Circumpolar Current 30 million years ago as Tasmanian Gateway aligned with westerlies. Nature, 523, 580. Retrieved from doi:10.1038/nature14598

SEPULCHRE, P., SLOAN, L. C., SNYDER, M., \& FIECHTER, J. (2009). Impacts of Andean uplift on the Humboldt Current system: A climate model sensitivity study. Paleoceanography, 24(4). doi:10.1029/2008PA001668

SHAFFER, G., HORMAZABAL, S., PIZARRO, O., \& RAMOS, M. (2004). Circulation and variability in the Chile Basin. Deep Sea Research Part I: Oceanographic Research Papers, 51(10), 1367-1386. doi:10.1016/j.dsr.2004.05.006

SHIPBOARD SCIENTIFIC PARTY (1976). Site 321. In DSDP Volume XXXIV, eds: R. S. Yeats and S. R. Hart, doi:10.2973/dsdp.proc.34.105.1976

SHIPBOARD SCIENTIFIC PARTY (1988). Introduction, objectives, and principal results, Leg 112, Peru continental margin. In Suess, E., von Huene, R., et al., Proc. ODP, Init. Repts., 112: College Station, TX (Ocean Drilling Program), 5-23.

doi:10.2973/odp.proc.ir.112.102.1988

SHIPBOARD SCIENTIFIC PARTY (1992). Introduction. In Mayer, L., Pisias, N., Janecek, T., et al., Proc. ODP, Init. Repts., 138: College Station, TX (Ocean Drilling Program), 5-12. doi:10.2973/odp.proc.ir.138.101.1992

SHIPBOARD SCIENTIFIC PARTY (1999). Leg 181 summary: Southwest Pacific paleoceanography. In Carter, R.M., McCave, I.N., Richter, C., Carter, L., et al., Proc. ODP, Init. Repts., 181: College Station, TX (Ocean Drilling Program), 1-80.

doi:10.2973/odp.proc.ir.181.101.2000

SHIPBOARD SCIENTIFIC PARTY (2003a). Leg 202 summary. In Mix, A.C., Tiedemann, R., Blum, P., et al., Proc. ODP, Init. Repts., 202: College Station, TX (Ocean Drilling Program), 1-145. doi:10.2973/odp.proc.ir.202.101.2003

SHIPBOARD SCIENTIFIC PARTY (2003b). Site 1231, Proc. Ocean Drill. Program Initial Rep. 201, 64 pp, doi:10.2973/odp.proc.ir.201.112.2003

SOUTHARD, J. B., YOUNG, R. A., \& HOLLISTER, C. D. (1971). Experimental erosion of calcareous ooze. Journal of Geophysical Research (1896-1977), 76(24), 5903-5909. https://doi.org/10.1029/JC076i024p05903

STEIN, C. A., \& STEIN, S. (1992). A model for the global variation in oceanic depth and heat flow with lithospheric age. Nature, 359(6391), 123-129. https://doi.org/10.1038/359123a0

TALLEY, L.D. (2013). Closure of the global overturning circulation through the Indian, Pacific, and Southern Oceans: Schematics and transports. Oceanography 26(1):80-97, https://doi.org/10.5670/oceanog.2013.07. 
Nazca Drift System - SE Pacific Ocean paleoceanography /doi:10.1017/S0016756821000960

TIEDEMANN, R., \& MIX, A. (2007). Leg 202 synthesis: southeast Pacific paleoceanography. In Tiedemann, R., Mix, A.C., Richter, C., and Ruddiman, W.F. (Eds.), Proc. ODP, Sci. Results, 202: College Station, TX (Ocean Drilling Program), 156. doi:10.2973/odp.proc.sr.202.201.2007

THRAN, A. C., DUTKIEWICZ, A., SPENCE, P., \& MÜLLER, R. D. (2018). Controls on the global distribution of contourite drifts: Insights from an eddy-resolving ocean model. Earth and Planetary Science Letters, 489, 228-240. doi:10.1016/j.epsl.2018.02.044

TSUCHIYA, M., \& L. D. TALLEY (1998), A Pacific hydrographic section at $88^{\circ} \mathrm{W}$ : Waterproperty distribution, J. Geophys. Res., 103(C6), 12,899-12,918, doi:10.1029/97JC03415.

VAIL, P. R., R. G., TODD, \& SANGREE, J. B. (1977), Seismic stratigraphy and global changes of sea level, Part 5: Chronostratigraphy significance of seismic relations, in Seismic Stratigraphy: Application to Hydrocarbon Exploration, edited by C. E. Payton, 8th ed., pp. 99-116, Am. Assoc. of Pet. Geol., Tulsa, Okla.

VELDE, B. (1996). Compaction trends of clay-rich deep sea sediments. Marine Geology, 133(3), 193-201. https://doi.org/https://doi.org/10.1016/0025-3227(96)00020-5

VON HUMBOLDT, A. (1816). Voyage aux régions équinoxiales du Nouveau Continent fait en 1799, 1800, 1801, 1802, 1803 et 1804, par Al. De Humboldt et A. Bonpland, rédigé par Alexandre de Humboldt, avec un atlas géographique et physique, Tome Second, 382p. Accès BnF Gallica. gallica.bnf.fr

VON HUENE, R., PECHER, I. A., \& GUTSCHER, M.-A. (1996). Development of the accretionary prism along Peru and material flux after subduction of Nazca Ridge. Tectonics, 15(1), 19-33. doi:10.1029/95TC02618

WRIGHT, N. M., SETON, M., WILLIAMS, S. E., \& MÜLLER, R. D. (2016). The Late Cretaceous to recent tectonic history of the Pacific Ocean basin. Earth-Science Reviews, 154, 138-173. doi:10.1016/j.earscirev.2015.11.015

YU, X., STOW, D., SMILLIE, Z., ESENTIA, I., BRACKENRIDGE, R., XIE, X. BANKOLE, S., DUCASSOU, E. \& LLAVE, E. (2020). Contourite porosity, grain size and reservoir characteristics. Marine and Petroleum Geology, 104392. https://doi.org/https://doi.org/10.1016/j.marpetgeo.2020.104392

ZACHOS, J., PAGANI, M., SLOAN, L., THOMAS, E., \& BILLUPS, K. (2001). Trends, Rhythms, and Aberrations in Global Climate 65 Ma to Present. Science, 292(5517), 686 LP - 693. Retrieved from http://science.sciencemag.org/content/292/5517/686.abstract 


\section{Г}
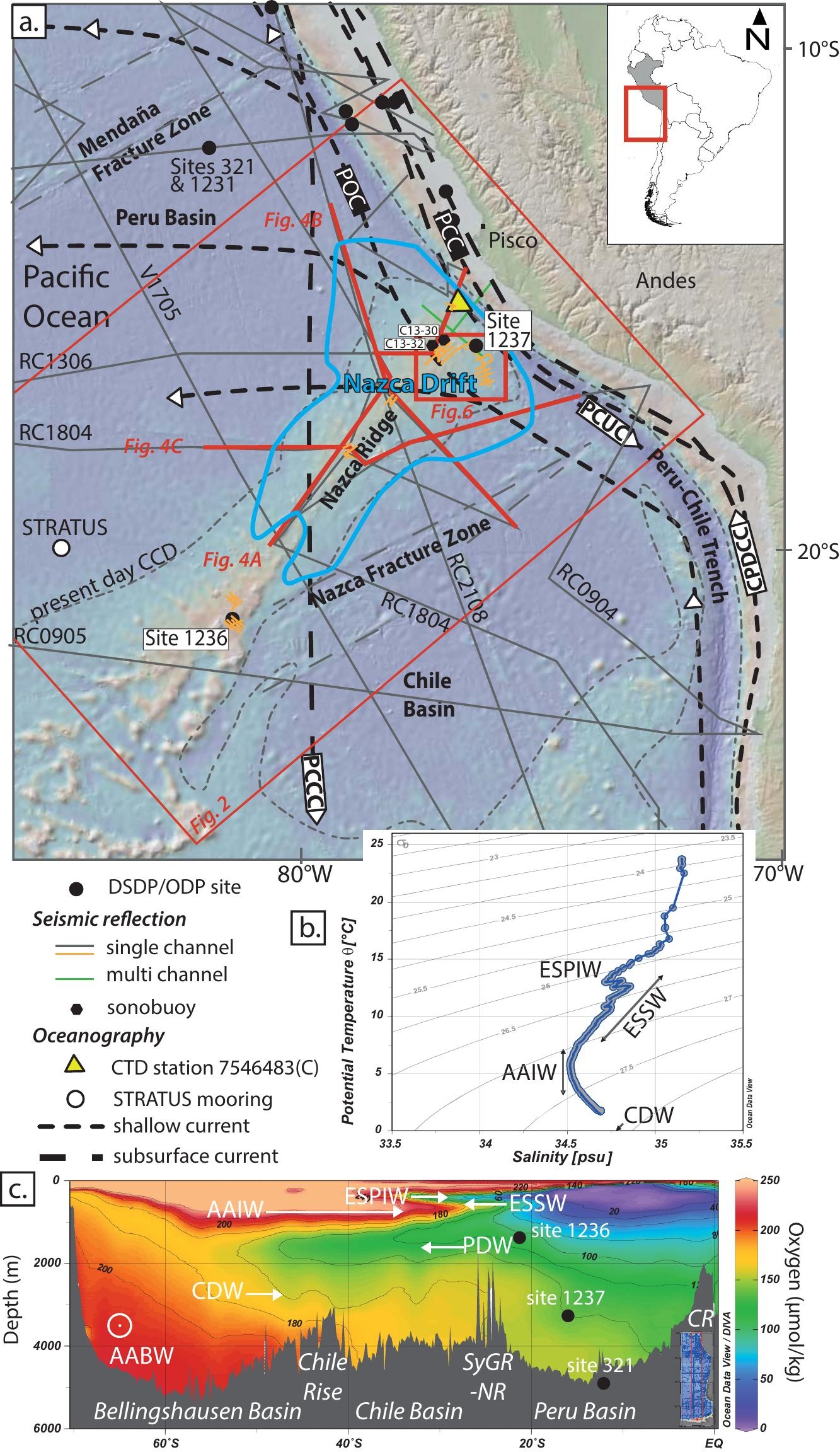


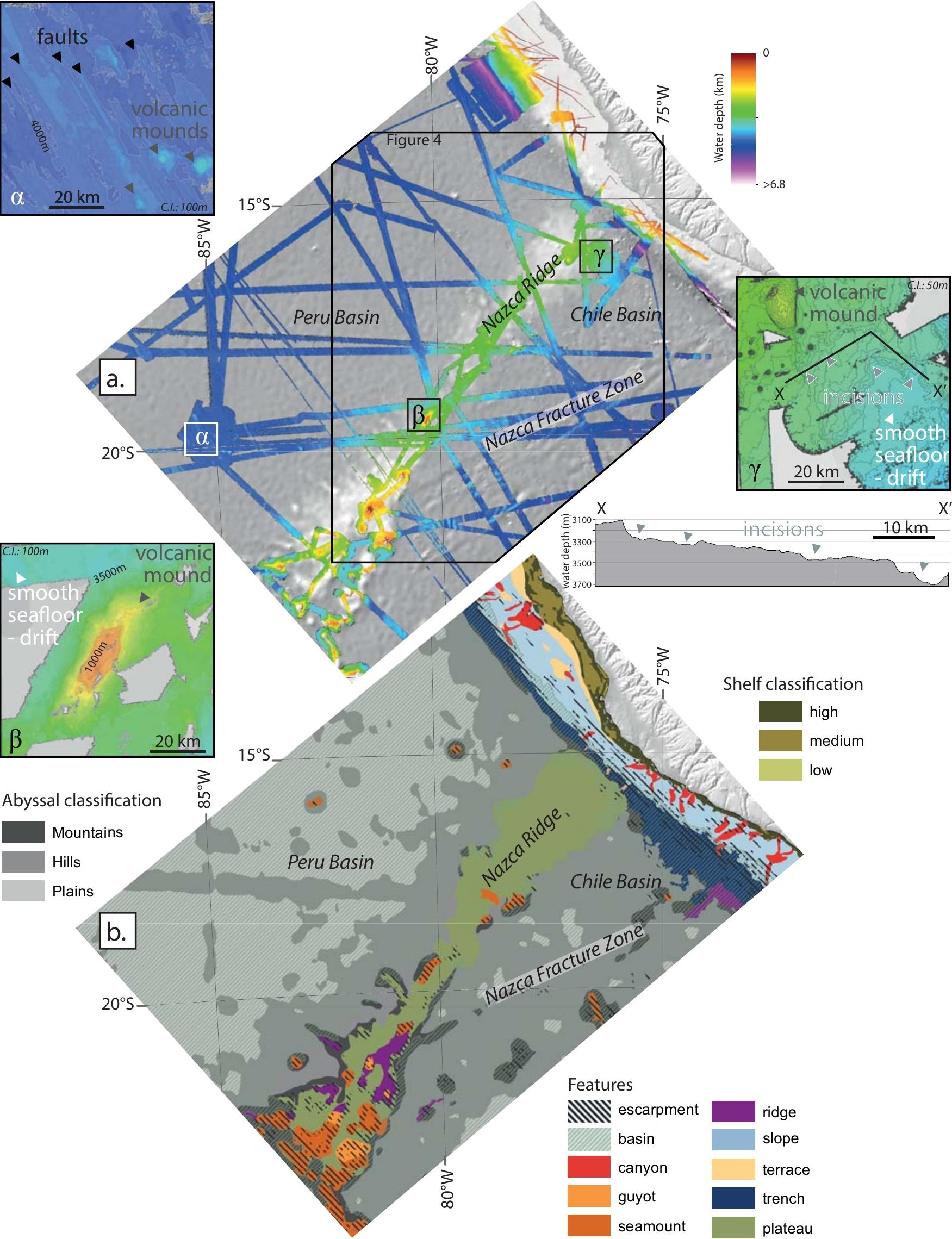



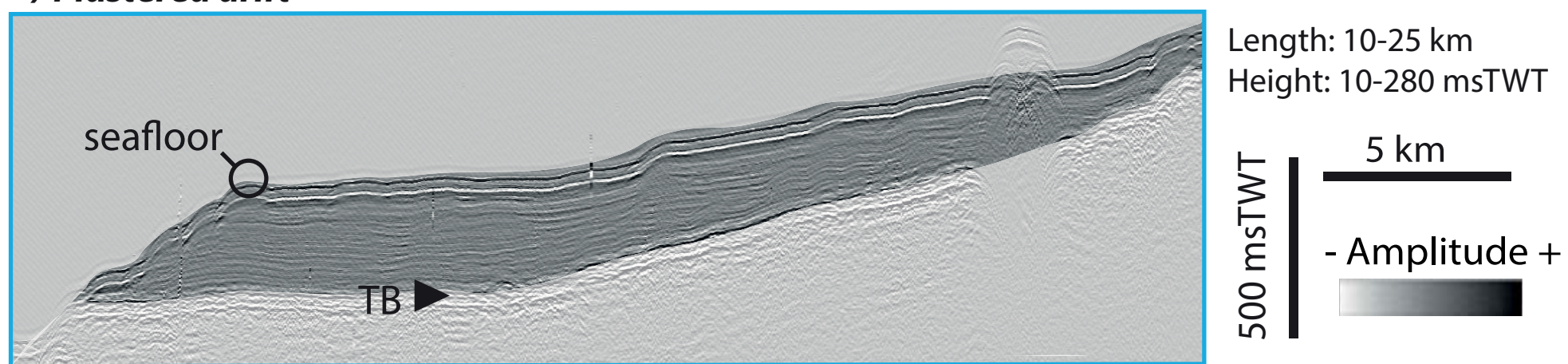

\section{b) Mounded separated/isolated drift}

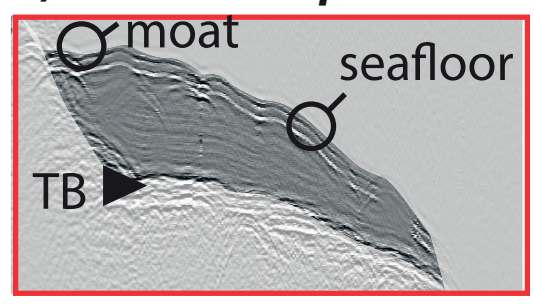

Mound / low amplitude Moat on the edge of high Background: parallel to wavy
Height: 0-250 msTWT

Length: 5-10 km

\section{c) Confined drift}

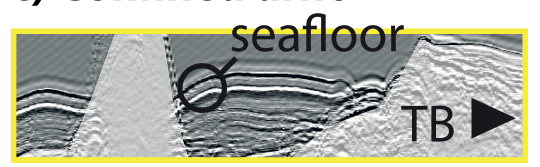

Mound / low to high amplitude Moat on the edges of highs Background: parallel to wavy
Length: 10->100s km

Height: 10-100 msTWT

\section{d) Fault/scarp controlled drft}

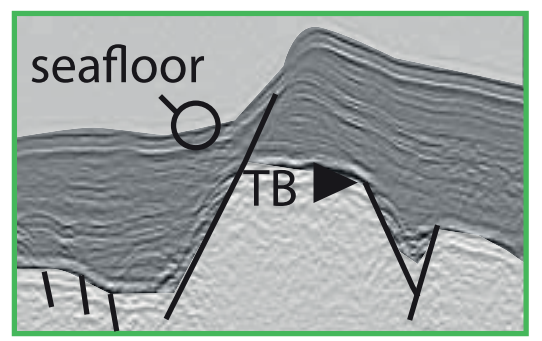

e) Sheeted/abyssal drift

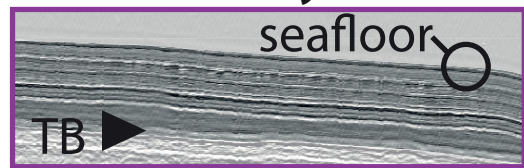

Mound-wedge / low amplitude Moat on the edge of highs Background: parallel to subparallel
Length: 10->70s km Height: 10->400 msTWT

Vertical exaggeration in sediments $\sim x 11$ and in volcanics $\sim x 4,4$

\section{f) Volcanic sill}

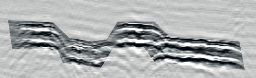

g) Volcanic mound

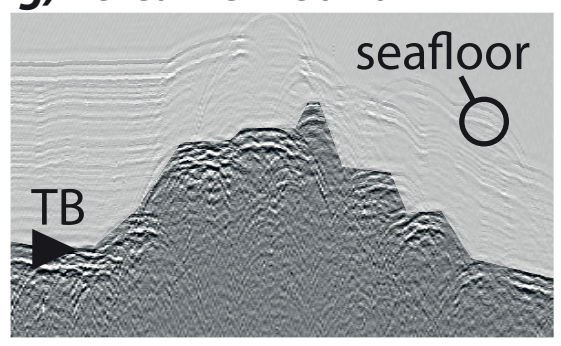

Single event / high amplitude

Cross-cutting reflection

Background: parallel to subparallel
Length: $0,5-5,5 \mathrm{~km}$

Height: 0,2-0,4 sTWT
Length: 10->100s km
Background: parallel to subparallel Height: 10-100 msTWT 


\section{a. \\ Nazca Drift System water depth (m)}

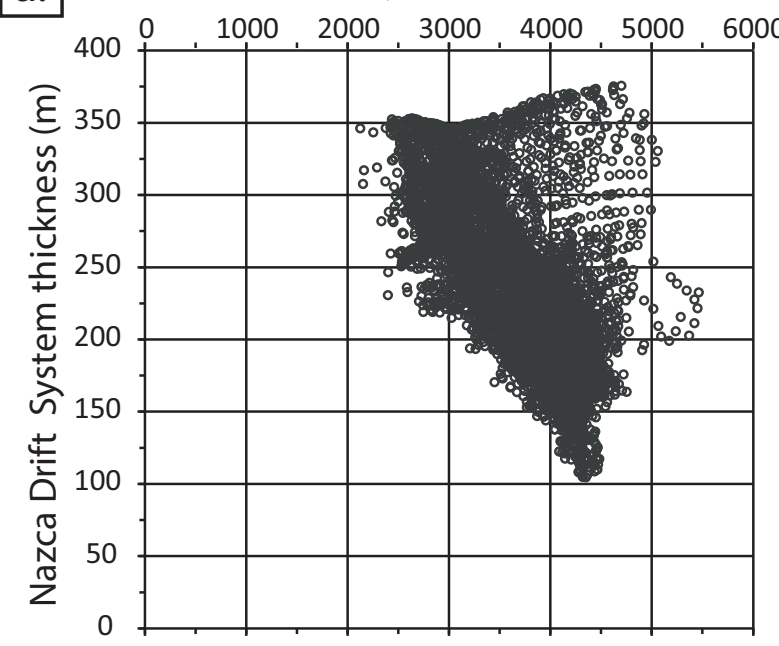

b.

Erosional truncation

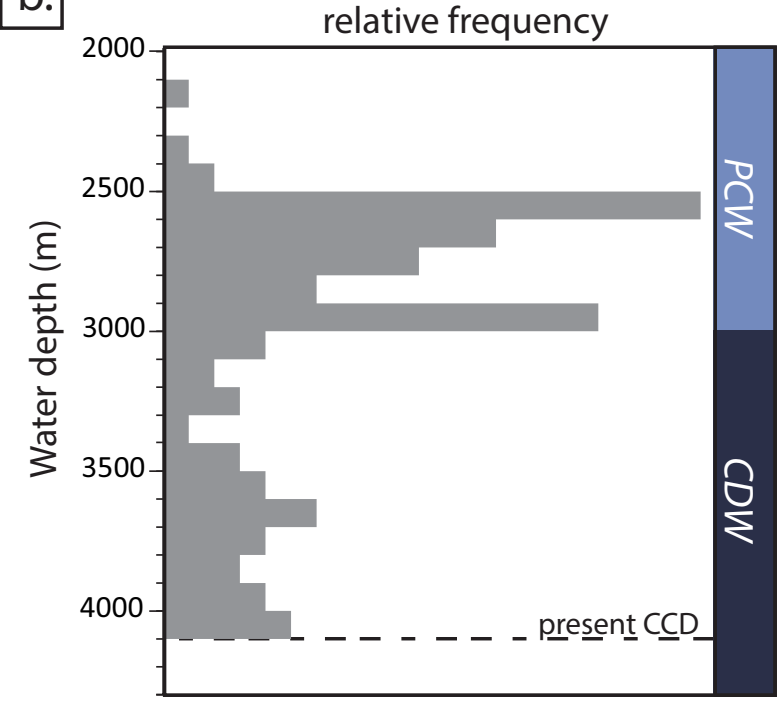

C.

C. Nazca Drift System water depth relative frequency

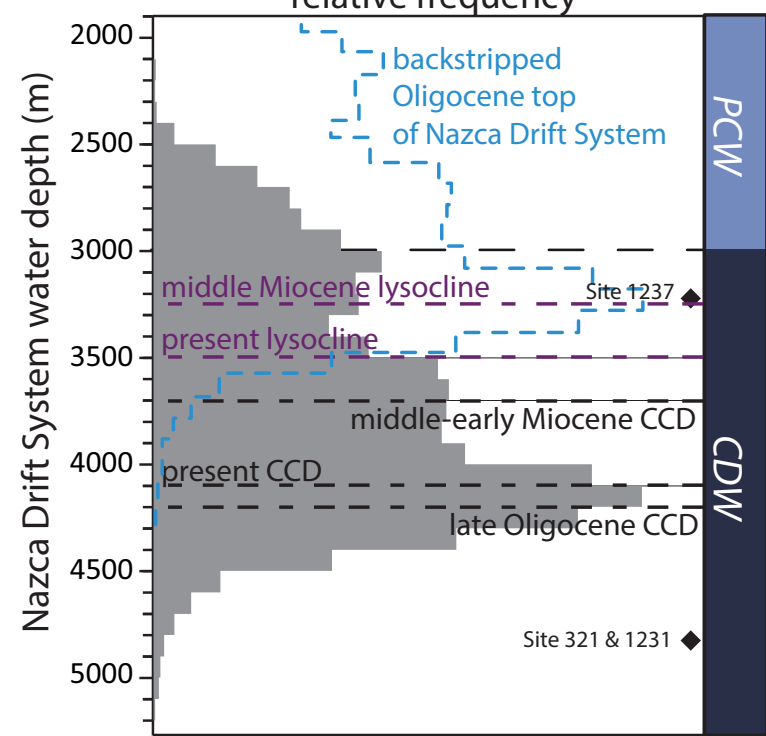




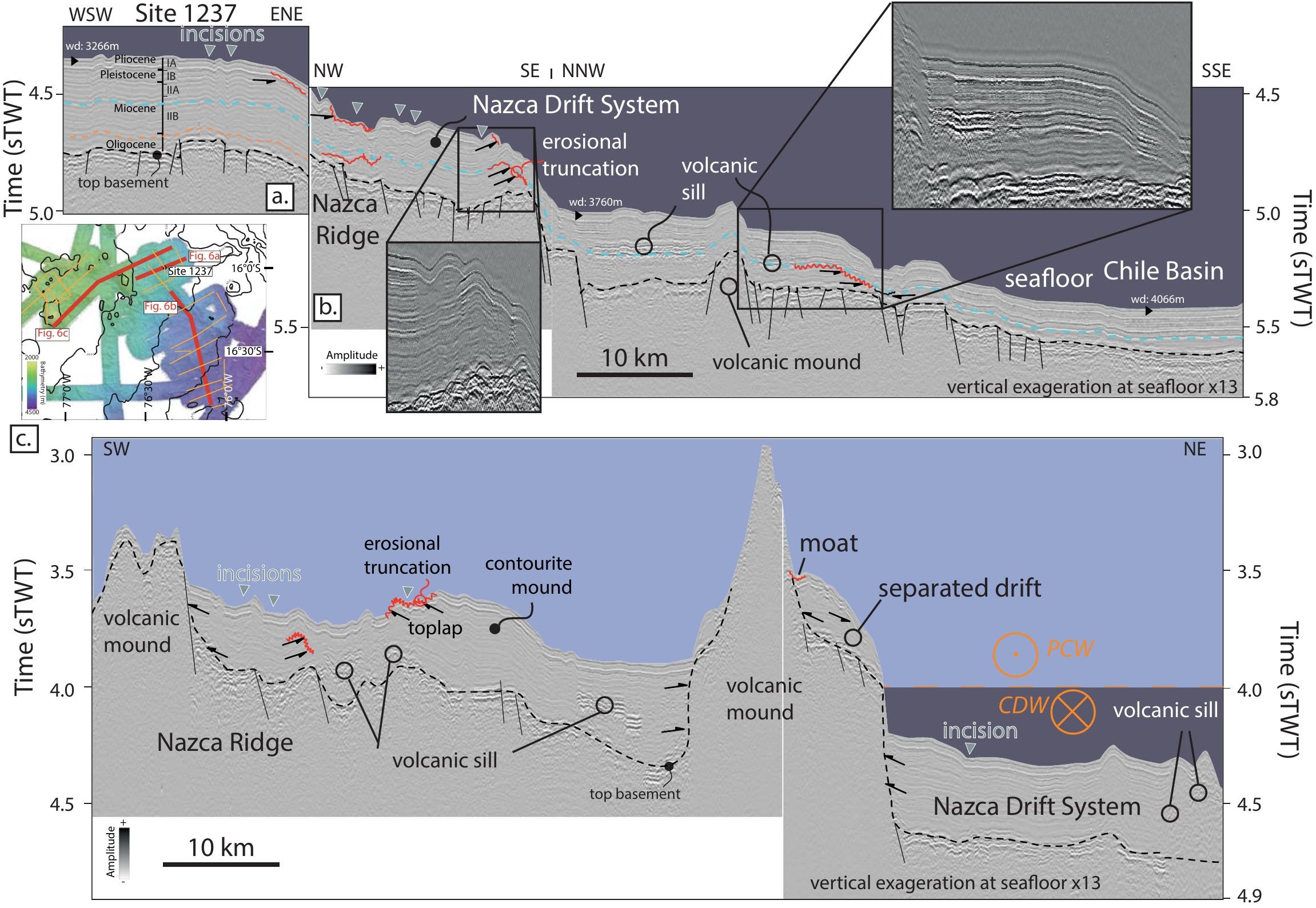




\section{a.}

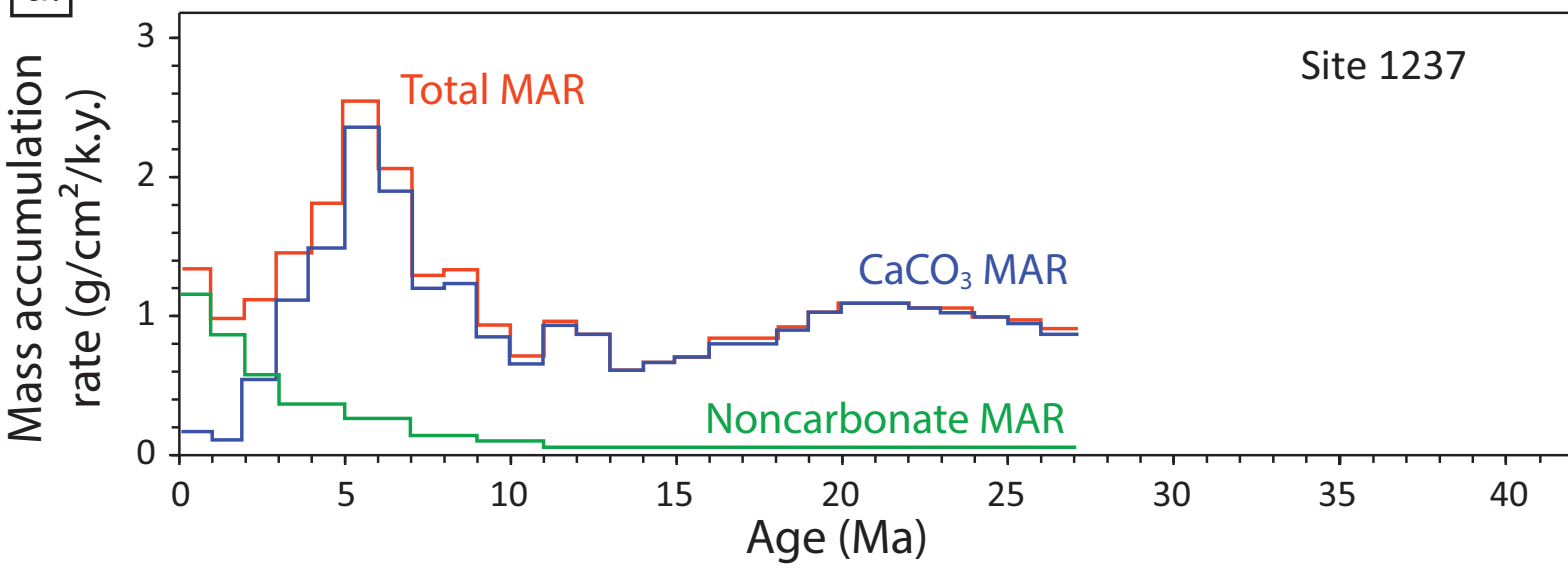

b.

c.

Antarctic ice-sheets

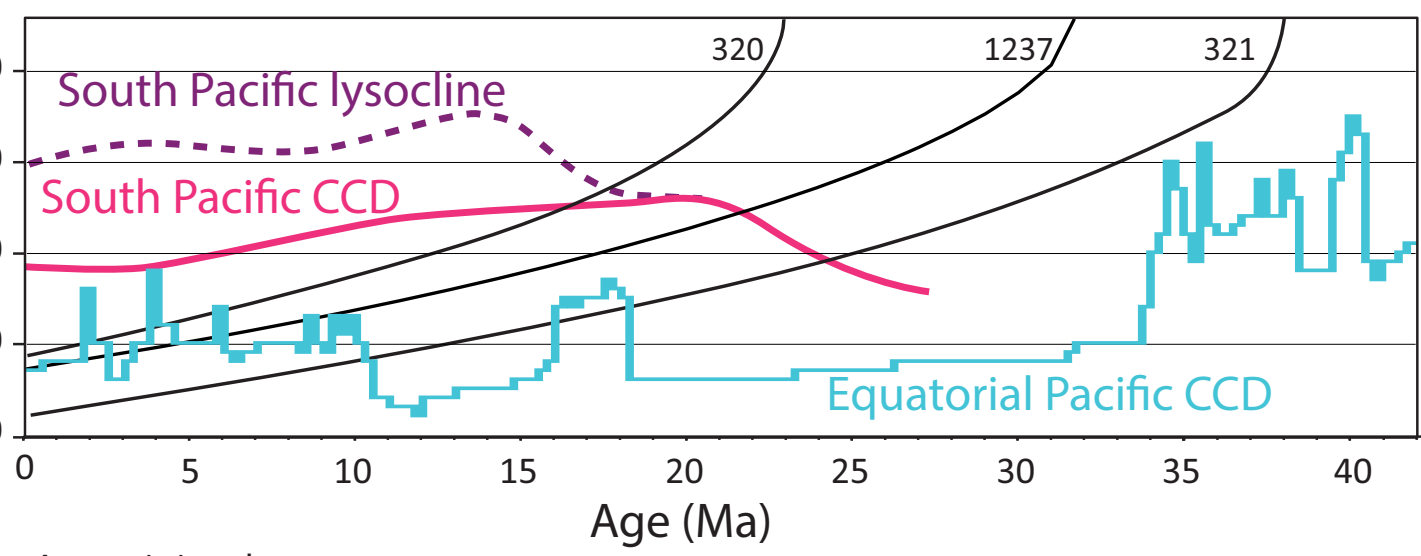

Northern Hemisphere ice-sheets
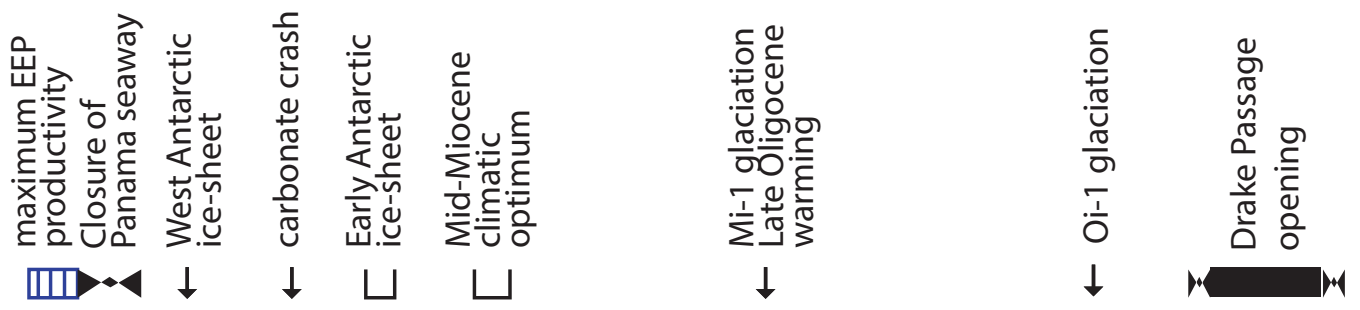

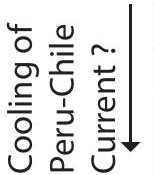

Temperature at Early Eocene climatic optimum 
'Geological Magazine', The Nazca Drift System - paleoceanographic significance of a giant sleeping on the SE Pacific Ocean floor, Calvès et al.,' 'Supplementary Material', Figure S1

A.
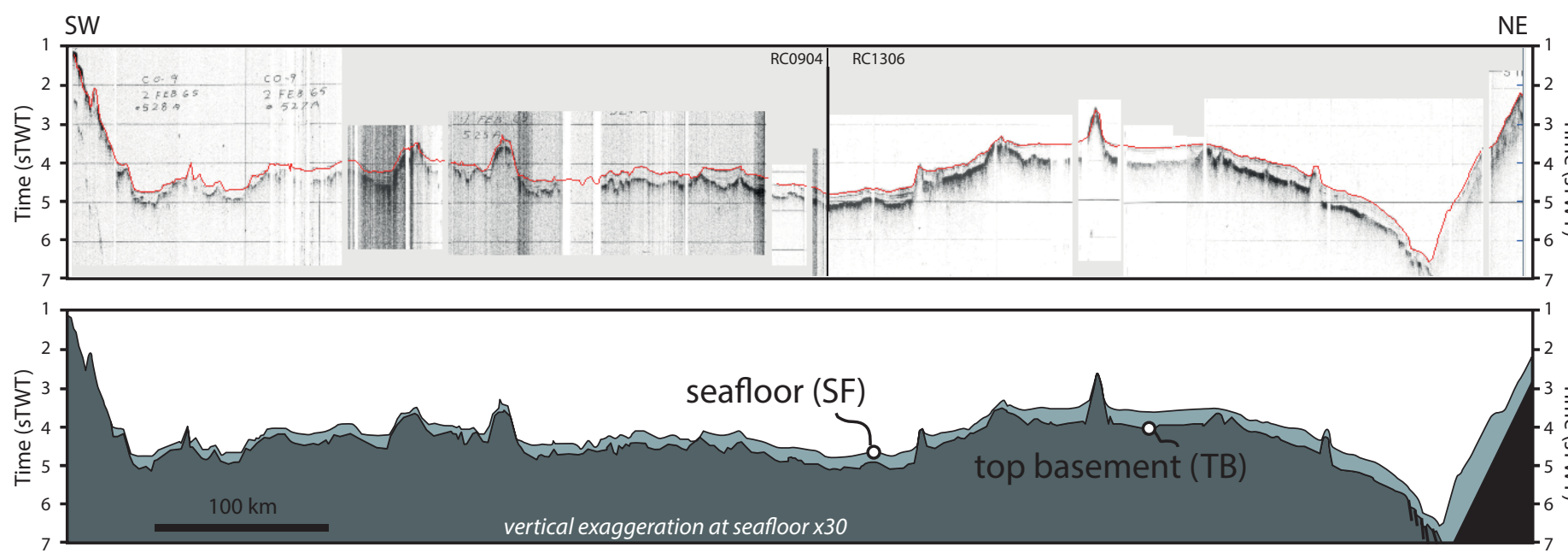

B.
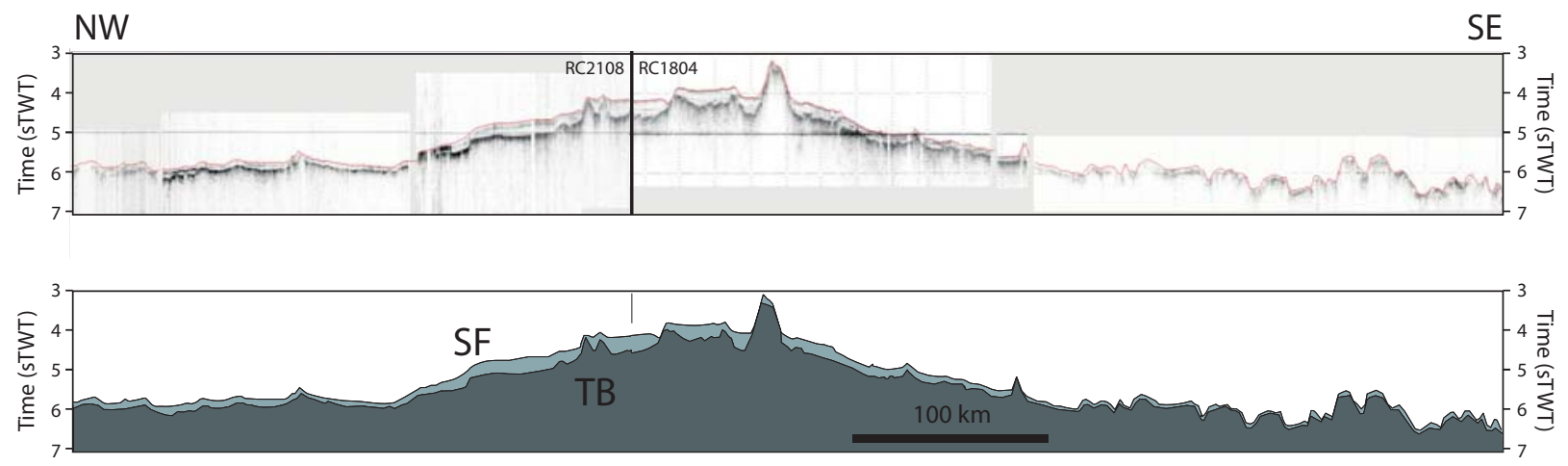

C.
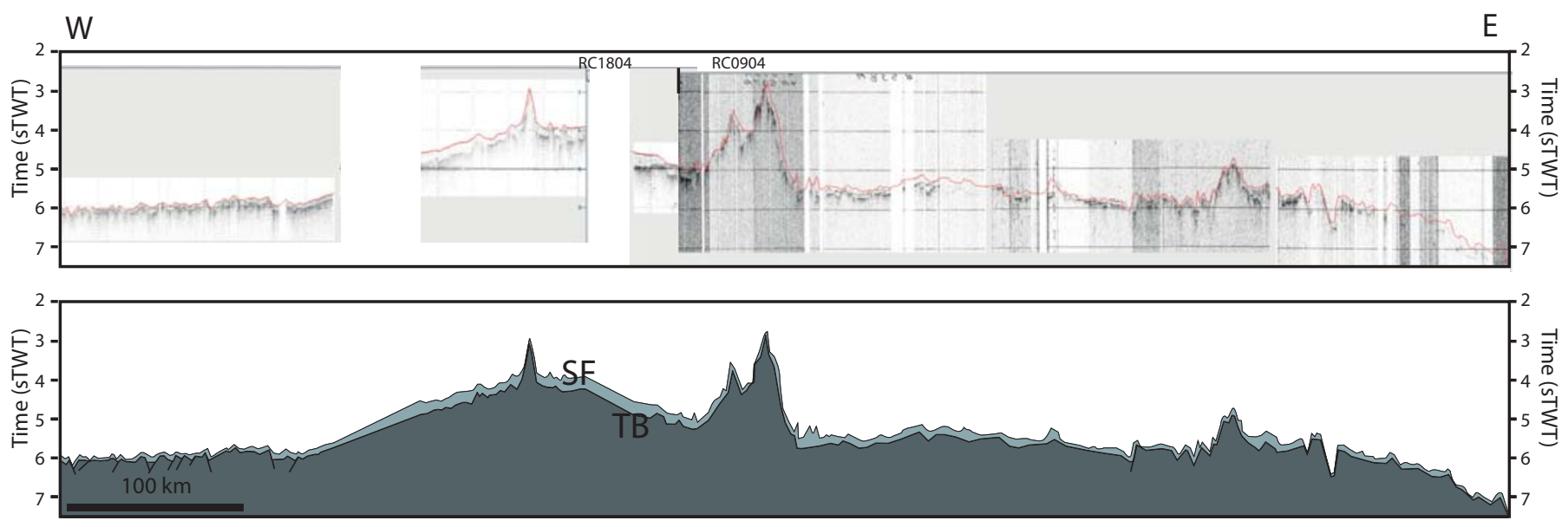

Figure S1: uninterpreted and interpreted single-channel seismic data related to Figure 4. Data source: https://www.ngdc.noaa.gov/mgg/seismicreflection/index.html 


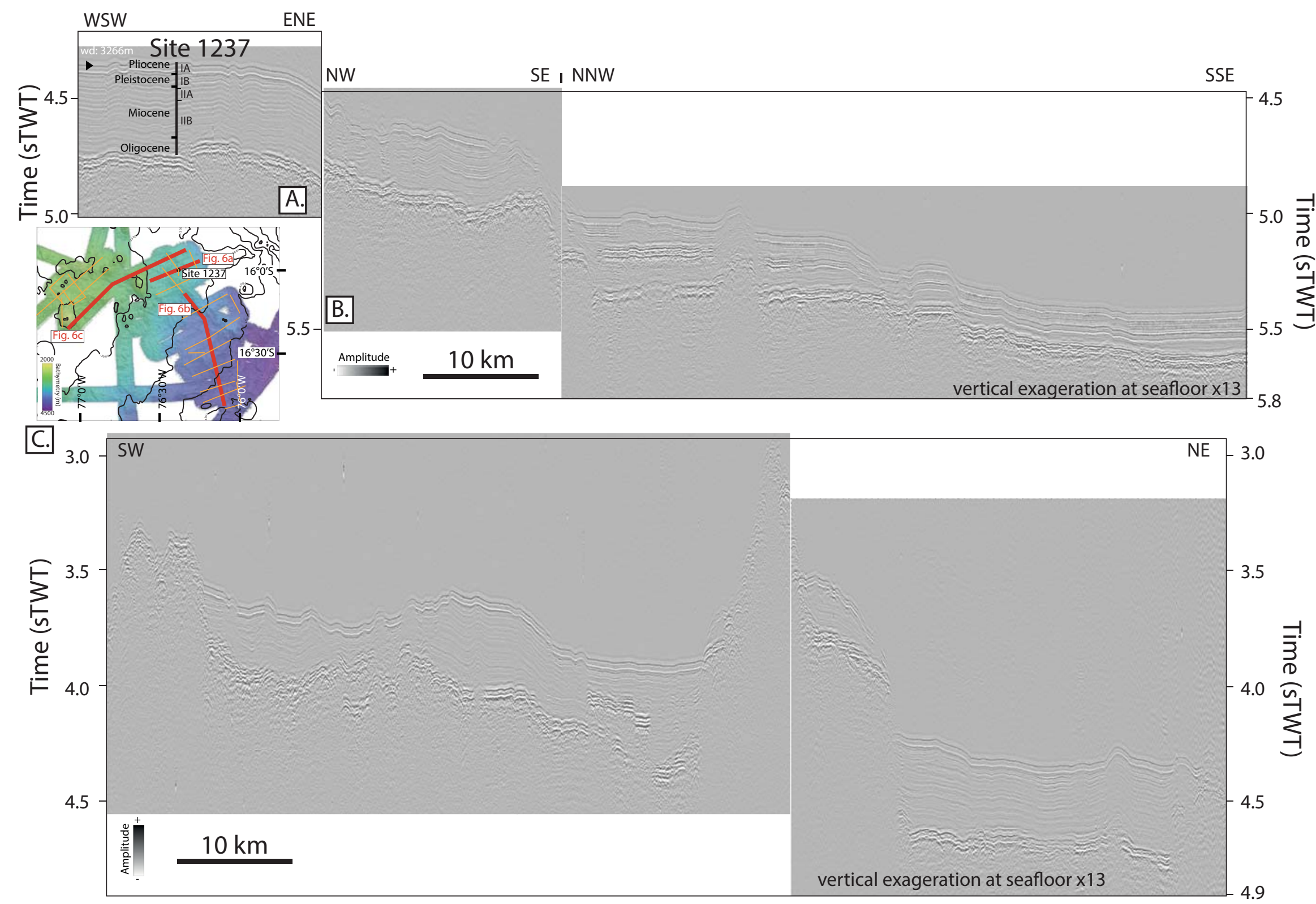

